\title{
Closing the Gap Between Watershed Modeling, Sediment Budgeting, and Stream Restoration
}

\author{
Sean M. C. Smith \\ Geography and Environmental Engineering, Johns Hopkins University, Baltimore, Maryland, USA \\ Patrick Belmont \\ Department of Watershed Sciences, Utah State University, Logan, Utah, USA \\ Peter R. Wilcock \\ Geography and Environmental Engineering, Johns Hopkins University, Baltimore, Maryland, USA
}

The connection between stream restoration and sediment budgeting runs both ways: stream restoration is proposed as a means to reduce sediment yields, but an accurate understanding of sediment supply is necessary to design an effective project. Recent advances in monitoring technology, geochemical techniques, high-resolution topography data, and numerical modeling provide new opportunities to estimate sediment erosion, transport, and deposition rates; upscale them in a geomorphically relevant fashion; and synthesize sediment dynamics at watershed scales. For practical application at large scale, watershed models used to predict yield often do not resolve lower-order channels, leaving an essential "blind spot" regarding sediment processes. We illustrate the challenges and emerging approaches for estimating sediment budgets using examples from two very different physiographic settings: the Mid-Atlantic Piedmont and the agricultural plains of southern Minnesota. We highlight common challenges and themes in defining an effective watershed sediment model. In both cases, reliable estimates of sediment yield depend essentially on the accurate identification of sediment sources and sinks and, hence, require careful delineation of landscape units and identification of dominant sediment sources and sinks. The primary elements needed to bridge the gap between sediment budgeting, watershed modeling, and stream restoration are (1) specificity regarding location, mechanism, and rates of erosion, (2) accurate accounting of sediment storage, (3) appropriate methods for upscaling local observations, (4) efficient means for incorporating multiple lines of evidence to constrain budget estimates, and (5) stream restoration methods that incorporate sediment supply in assessment and design procedures.

Stream Restoration in Dynamic Fluvial Systems: Scientific Approaches, Analyses, and Tools

Geophysical Monograph Series 194

Copyright 2011 by the American Geophysical Union.

10.1029/2011GM001085

\section{INTRODUCTION}

The need for estimates of sediment sources and yields is not new; this is a field with a long and rich history of research and application. Sediment fluxes and their mass balance, a 
sediment budget, have been developed for both research and management purposes. The need for such work has intensified with the increasing recognition of the effect of sediment and turbidity on the health of receiving waters and with the advent of total maximum daily loads (TMDLs) specified for sediment or turbidity reduction. Stream restoration is increasingly viewed as a viable option for reducing sediment loads.

The connection between stream restoration and sediment budgets runs both ways: stream restoration is not only proposed as a means to reduce sediment yields, but an accurate understanding of sediment supply is often needed to design an effective stream restoration project. The two directions are closely linked in practice, addressing questions such as the following: Where is the best place in the watershed to reduce sediment yield? Over what time period will sediment reductions occur at the watershed outlet? What is the sediment supply to a designated restoration site over different time scales? How can information on location and rates of erosion and deposition guide the selection of best management practices? In either direction, practical application of sediment budget information requires that sources and sinks be specifically identified as to location, mechanism, controls, and rates.

Watershed hydrologic models are increasingly used to predict sediment yields. By predicting water flux and applying a sediment mass balance, such models provide a potentially powerful tool for estimating sediment supply and yield. They have also increased in their resolution and the number of physical processes that are simulated [e.g., Flanagan and Nearing, 1995; Langendoen, 2002; Neitsch et al., 2005]. However, such models face difficult challenges when applied to a range of watershed scales.

1. Sediment erosion and deposition are extremely variable in place and in time, with the bulk of sediment movement often happening in highly localized, short-term events, which makes prediction of sediment yield as a function of temporal and spatial mean quantities prone to large error.

2. Entrainment, transport, and deposition mechanisms are nonlinear with respect to the driving water flux and the sediment available for transport. This leads to potentially large errors from even relatively small errors in flow and sediment input.

3. The fraction of eroded sediment that is stored between source and sink can vary from zero to unity and the duration of storage can range from intraevent to geological. Some watershed models now include overland and channel components and can compute storage changes at a fine spatial and temporal scale, but none have been demonstrated to adequately represent sediment storage and release across all scales.

For practical application at large scale, watershed models often do not resolve lower-order channels, leaving an essen- tial "blind spot" regarding sediment processes. Low-order channels can act as net sources or sinks of sediment. Their dynamics can include a suite of mechanisms that differ strongly from those acting within upland hillslopes or larger valley bottoms. These distinctions are essential in developing a reliable estimate of sediment supply and for focusing restoration efforts. If, for example, a watershed model includes only third- and higher-order channels, the sediment dynamics of first- and second-order streams are necessarily grouped into a simple, often scalar parameter that specifies the fraction of the upland sediment production delivered to the stream network. Because a large fraction of most watersheds is drained via first- and second-order channels, representing these features by a simple filter or delivery factor can result in substantial error. Values reported for sediment delivery ratios (the ratio of sediment yield to sediment production) vary from $>1$ to $<0.1$ [Walling, 1983; De Vente et al., 2007], indicating that reliable, independent estimates of sediment sources and sinks are essential if watershed sediment budgets are to be successfully connected to stream restoration projects.

The emerging availability of high-resolution topography and GIS offers the opportunity for more realistic representation of sediment processes in low-order subwatersheds, but reliable and efficient methods have not yet been assembled into a widely used package. One approach to addressing the resolution problem uses watershed models that implement physical relations governing sediment production, flux, storage, and delivery at high spatial resolution [e.g., Flanagan and Nearing, 1995]. Although defined explicitly, the mechanisms incorporated may not represent the actual suite of mechanisms and their rates at the process scale. Indeed, the physical basis for these models can become a limitation when insufficient information is available to specify the many detailed boundary conditions required. Further, the specific physical relations used in these models must be applied to a wide range of topographic and hydraulic conditions over which they are unlikely to apply consistently.

In response to these challenges, watershed sediment models can be modified to incorporate independent information on sediment sources and sinks. For example, a Hydrological Simulation Program - Fortran (HSPF) model of the Minnesota River Basin uses sediment fingerprinting results to constrain the proportion of sediment derived from different sources [Tetra Tech, Inc., 2008]. In the examples presented here, net sediment contributions from colluvial deposits, floodplains, and stream banks are determined from direct observation and upscaled using topographic analysis to estimate the area and location of sites serving as net sources and sinks. Sediment fingerprinting techniques are used to estimate the proportion of the yield derived from agricultural 
fields. When such independent information is used to constrain the results of a watershed model, the model provides a useful role as an accounting system for the sediment mass balance, but its ability to predict future sediment yield is no better than the independent information used.

The need for direct observation of sediment sources and sinks and for using multiple lines of evidence to constrain a sediment mass balance differs little from sediment budgets assembled in the predigital era. The challenge at present is to develop a system within which the power of watershed numerical models can fully integrate available information and for which the predictive capability of supplemental information is demonstrated. The nature of the information will necessarily vary with circumstance and conditions in different watersheds, and an effective combination of approaches is needed to close the gap in predicting watershed sediment yield.

The primary elements needed to bridge the gap between sediment budgeting, watershed modeling, and stream restoration are (1) specificity regarding location, mechanism, and rates of sediment erosion, (2) accurate treatment of changes in sediment storage, (3) appropriate methods for upscaling local observations, (4) efficient means for incorporating multiple lines of evidence to constrain budget estimates, and (5) stream restoration methods that effectively incorporate sediment supply in assessment and design procedures. A combination of existing and new technology provides an excellent opportunity to estimate sediment sources and sinks in a manner that discretizes over space and integrates over time, including (1) field observations and spatial analysis of topography, soil distribution, and land cover to locate, quantify, and upscale erosion estimates in a way that accounts for the effects of geomorphic setting and watershed location on sediment supply and (2) measurements of sediment accumulation in ponds, reservoirs, and lakes combined with radiogenic and isotopic chemistry methods for sediment fingerprinting and dating to develop a reliable estimate of sediment yield over decade to century time scales in order to provide a strong constraint on estimated sediment budgets.

We illustrate the challenges and emerging approaches for estimating sediment budgets using examples from two very different physiographic settings: the Mid-Atlantic Piedmont and the agricultural plains of southern Minnesota. Relief, watershed age, climate, and land use histories differ substantially between the two. However, reliable estimates of sediment yield and specification of restoration alternatives depend essentially on accurate identification of sediment sources and sinks in both cases, phenomena that have not been well captured in existing modeling approaches. The cases we describe in this chapter do not represent the balance of sediment processes in all regions. For example, sediment budgets in mountainous and arid watersheds can be dominated by episodic delivery of coarse sediment to the channel network, processes that are present but less significant in the cases presented here. Although the imperative to accurately identify mechanisms, locations, and rates of sediment delivery is the same in mountainous watersheds, the spectrum of processes and the methods needed to quantify them (e.g., landslide and road inventories) are different and have been well summarized by the work of Reid and Dunne [1996, 2003].

\section{APPROACHES FOR WATERSHED SEDIMENT MODELING}

\subsection{Universal Soil Loss Equation}

The universal soil loss equation (USLE) has been a primary tool for estimating long-term average erosion rates for decades [Wischmeier and Smith, 1978; Soil and Water Conservation Society, 2003]. This approach applies estimated rainfall and runoff conditions to erosion, soil erodability, slope conditions, and land management techniques. Extensive data from plot studies have been assembled throughout the past century in support of the model. The USLE has often been used to predict upland sediment supply. However, a shortcoming of the model and its revised forms, RUSLE and RUSLE2, is the ability to relate erosion at the plot scale to sediment delivery to the river channel network and outlets of large watersheds [Renard et al., 1997; Trimble and Crosson, 2004]. This is the original "gap" between sediment production and yield that recent work has tried to address. Accounting for sediment delivery motivated the development of a subsequent version of the model called the modified USLE or MUSLE through direct consideration of runoff rates and hillslope curvature [Williams, 1975]. The MUSLE approach was designed to estimate sediment delivered from small watersheds for individual storms.

Wischmeier and Smith [1978] identified limitations of the USLE for predicting sediment supply. Later modifications improved adaptability, time resolution, and prediction of small watershed sediment delivery, but the model is fundamentally limited by the lack of terms to estimate erosion, deposition, and transport in both colluvial and alluvial settings. Accurately scaling up USLE estimates to large watersheds has been criticized for being impractical for these reasons [Boomer et al., 2008].

Despite the limitations, USLE and its descendents remain highly useful for the appropriate purpose: estimating sediment yield at the field scale, particularly because of the rich legacy of plot observations and broad availability of Natural Resources Conservation Service (NRCS) county soil 
surveys, which include site-specific values needed to use the model. The USLE remains the most thoroughly tested approach for field-scale erosion estimation. At the same time, there is abundant evidence that USLE cannot do what it was not intended to do: estimate the transport and fate of sediment once it leaves the field.

\subsection{Hydrologic Models With Sediment Flux Components}

Demands for large basin sediment yield estimates have led to widespread use of watershed hydrology models as loading and transport simulation tools. Multiple models have been developed that used lumped parameter approaches to watershed simulation. Among those commonly used in the United States are the Soil and Water Assessment Tool (SWAT) [Arnold et al., 1998] and HSPF [Bicknell et al., 2001]. HSPF is a component of the Better Assessment Science Integrating Point and Non-point Sources environmental analysis system and a primary watershed modeling tool of the U.S. Environmental Protection Agency (U.S. EPA). HSPF provides a platform for continuous simulation of surface and subsurface hydrology and suspended sediment transport [Donigian and Huber, 1991; Bicknell et al., 2001; U.S. Environmental Protection Agency (U.S. EPA), 2008]. The model allows for the integrated simulation of land and soil runoff processes coupled with terms to represent simplified river hydraulic conditions related to sediment deposition and transport.

HSPF is framed with some physical basis for detaching and routing sediment downstream. Nonetheless, the modeling "gap" remains in its application, as illustrated by the application of the model to the Chesapeake Bay watershed. Erosion from the land surface is simulated using a continu- ous time series of precipitation combined with specified land uses to calculate edge-of-field (EOF) loads that are calibrated to estimates of soil erosion from the RUSLE and adjusted relative to the efficiency of implemented best management practices (NRCS, National Resources Inventory, 2003-Soil Erosion, U.S. Department of Agriculture, 2007, accessed 23 June 2011, http://www.nrcs.usda.gov/technical/NRI/ 2007/nri07erosion.html, hereinafter referred to as NRCS, data, 2007). EOF loads are delivered to the stream network after reduction by a scalar sediment delivery factor that is a function of drainage area [Roehl, 1962; Natural Resources Conservation Service (NRCS), 1983; U.S. EPA, 2008]. In the latest version of the Chesapeake model, the minimum stream size is prescribed by an annual average flow rate of $2.83 \mathrm{~m}^{3}$ $\mathrm{s}^{-1}$, which typically corresponds to streams of third or fourth order. Smaller river segments can be included in simulations, but headwater streams are not modeled when HSPF is applied for TMDL purposes in most watersheds in Maryland where we have focused attention here. The relatively large size of the rivers considered by the model and exclusion of smaller tributaries establishes a substantial gap in the watershed simulations (Figure 1). The range of erosion and deposition processes in lower-order streams are complex and vary among physiographic settings, making the universal application of a single delivery operator in the model a large source of uncertainty.

\subsection{Hydrologic/Hydraulic/Geomorphic Erosion Models}

More recent tools used by the U.S. Department of Agriculture (USDA) to estimate soil erosion have been compiled within the Water Erosion Prediction Project (WEPP). WEPP

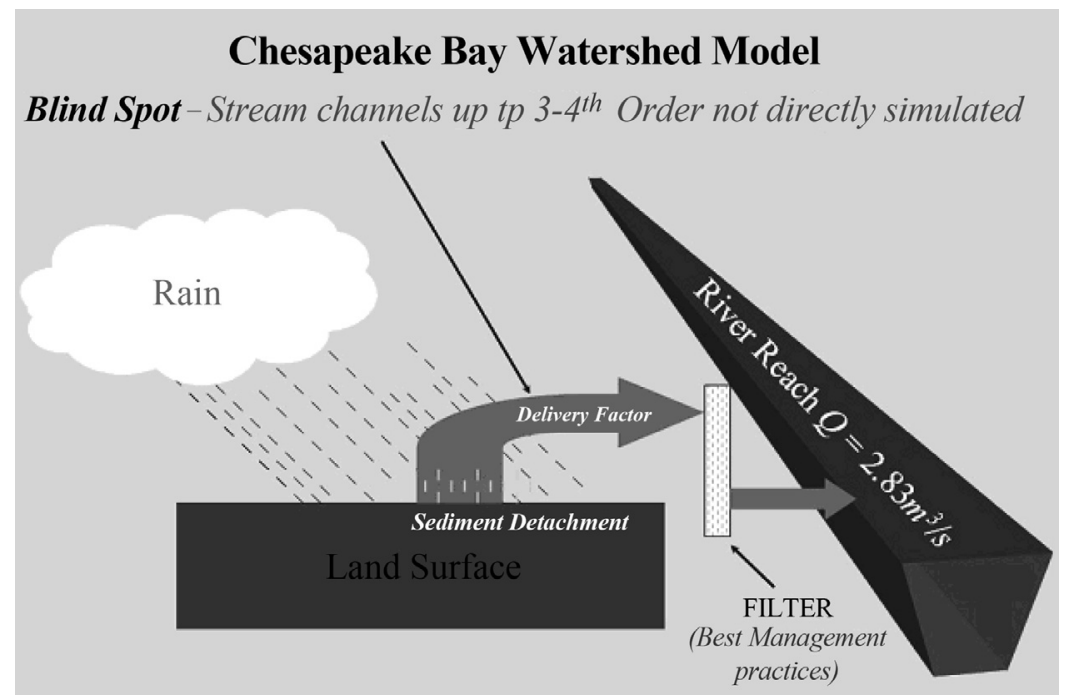

Figure 1. Chesapeake Bay watershed model framework. Source is G. Shenk, U.S. EPA Chesapeake Bay Program. 
uses a process-based simulation approach for hillsides and small watersheds [Foster and Lane, 1987; Flanagan and Nearing, 1995]. WEPP components include databases and subroutines for climate, hydrology, hydraulics, plant growth, and soil conditions. Sediment erosion and deposition are simulated using a steady state continuity equation and processbased transport rates for fields and small waterways. Gully erosion processes are not included despite their relevance to watershed sediment yield [Howard, 1999]. Accumulating local calculations of flow and sediment transport to larger scales requires specification of spatially and temporally varied soil, hydraulic, topographic, and vegetation conditions. Parameterization and input specification is a daunting task for practical application of process-based models like WEPP to large watersheds [Scatena, 1987].

Channel processes are explicitly incorporated in the USDA Conservational Channel Evolution and Pollutant Transport System [Langendoen, 2000, 2002]. The model simulates sediment transport and channel morphology using an unsteady one-dimensional hydraulic model that relates calculated transport capacity to upstream sediment supply in order to determine sediment erosion and deposition. Channel width adjustment can be estimated based on simulated bank material entrainment and bank gravity failure using input streambed and bank information. Floodplain processes are not simulated, so the effects of overbank flooding on hydraulic conditions and sediment storage are not quantified. Although the model includes a larger suite of physical mechanisms than spatially lumped models, model accuracy still faces the challenges of unresolved local heterogeneities and error amplification when using averaged quantities to estimate flux with nonlinear relations.

Watershed models bring obvious benefits to the problem of estimating sediment supply and yield. Physical mechanisms can be explicitly incorporated, sediment can be routed over long distances, and the models can provide a useful basis for developing a sediment mass balance. Each model has strong points and weaknesses, but none provides a complete framework that reliably identifies and predicts all production, transport, and storage terms at the appropriate time and space scales within a system that is practicable for typical watershed management and stream restoration applications. We argue that successful sediment supply and yield estimates must combine watershed modeling with the classical sediment budget imperative to apply multiple lines of independent evidence. This evidence can be developed using a mix of existing and new field, remote sensing, fingerprinting, and analysis techniques. A key challenge is to develop a watershed modeling system that can accommodate a diverse range of local and integral measures of sediment flux and storage.

\section{SEDIMENT YIELD IN THE MID-ATLANTIC PIEDMONT PROVINCE}

\subsection{Site Description}

The Piedmont Plateau physiographic province comprises nearly $23 \%$ of the $165,759 \mathrm{~km}^{2}$ Chesapeake Bay watershed [Langland et al., 1995]. The province is an old, dissected landscape dominantly composed of metamorphic crystalline bedrock such as schist, quartzite, and gneiss, with some areas underlain by carbonate bedrock [Smith et al., 2009]. The Blue Ridge physiographic province abuts the western side of the Piedmont, and the eastern side has a boundary coinciding with a relatively abrupt drop in the bedrock surface below an overburden of Coastal Plain sediment. This "fall zone" transition of the bedrock defines the head of navigable waters and a location attractive for hydropower in the colonial period, focusing development of urban centers that continue to grow today.

Once dominated by temperate humid forests, large-scale European colonization began about 350 years ago, resulting in extensive deforestation of the landscape and conversion of the land to agriculture [Grumet, 2000]. Forest cover of the region was smallest around the turn of the nineteenth century, with some recovery occurring in the twentieth century as a result of the decline in agriculture [Brush, 2008]. A second significant landscape conversion is still underway with suburban development increasing in the region over the past century.

Historic changes in land and river use have created a complex system of watershed sediment supply and delivery in the contemporary landscape. The conversion to agriculture and transition to suburban development substantially altered watershed hydrology and sedimentation patterns [Gottschalk, 1945; Wolman and Schick, 1967; Jacobsen and Coleman, 1986]. Extensive soil erosion during the peak agricultural period produced intense sediment delivery to valley bottoms and eventually to the Chesapeake Bay. A large fraction of the eroded sediment was stored as colluvium in upland areas or alluvium within valleys [Costa, 1975]. Evacuation of the deposits may take hundreds to thousands of years at the current rates of removal and replacement [Scatena, 1987]. Widespread construction of mill ponds augmented the storage of fine sediment along river channels [Happ, 1945; Walter and Merritts, 2008]. Breaching or intentional removal of these dams represents a potentially important perturbation and modern source of fine sediment to the channel network [Schenk and Hupp, 2009].

Concern about sediment supply has increased over the recent decades, as efforts to improve water quality in the Chesapeake Bay have proved largely ineffective [U.S. EPA, 
2008]. Sediment and turbidity, along with nitrogen and phosphorous, are identified as critical pollutants requiring reduction [U.S. EPA, 2010; Chesapeake Bay Program, Chesapeake 2000, Chesapeake Bay agreement, 2000, available at http:// www.chesapeakebay.net/content/publications/cbp_12081. pdf]. Stream bank stabilization and floodplain storage are increasingly seen as alternatives for reducing sediment loading to the Bay [Langland and Cronin, 2003; Hassett et al., 2005]. Management efforts require specificity regarding sediment source location and amount, which provided the motivation to develop a sediment budget for a Piedmont watershed in Maryland.

We focus here on the upper Patuxent River watershed (UPRW), a $203 \mathrm{~km}^{2}$ watershed draining relatively homogenous Mid-Atlantic Piedmont physiography (Figure 2) [Reger and Cleaves, 2003]. Land cover in the watershed is a mix of forest, field, and suburban development whose proportions have remained relatively stable over the past half-century. The Patuxent River is a fifth-order tributary at the downstream extent of the study area, where it is impounded by the Triadelphia Reservoir. The reservoir was constructed in 1943, and approximately decadal bathymetric surveys provide a record of sediment yield over more than 50 years. A U.S. Geological Survey (USGS) gauge at the town of Unity is located on the Patuxent River main stem immediately above the reservoir and has provided a continuous flow record from 1944 with periodic measurements of suspended sediment [Lizarraga, 1999]. Sediment load has also been estimated for the UPRW for the purpose of TMDL requirements using flow records, sediment grab samples, USGS

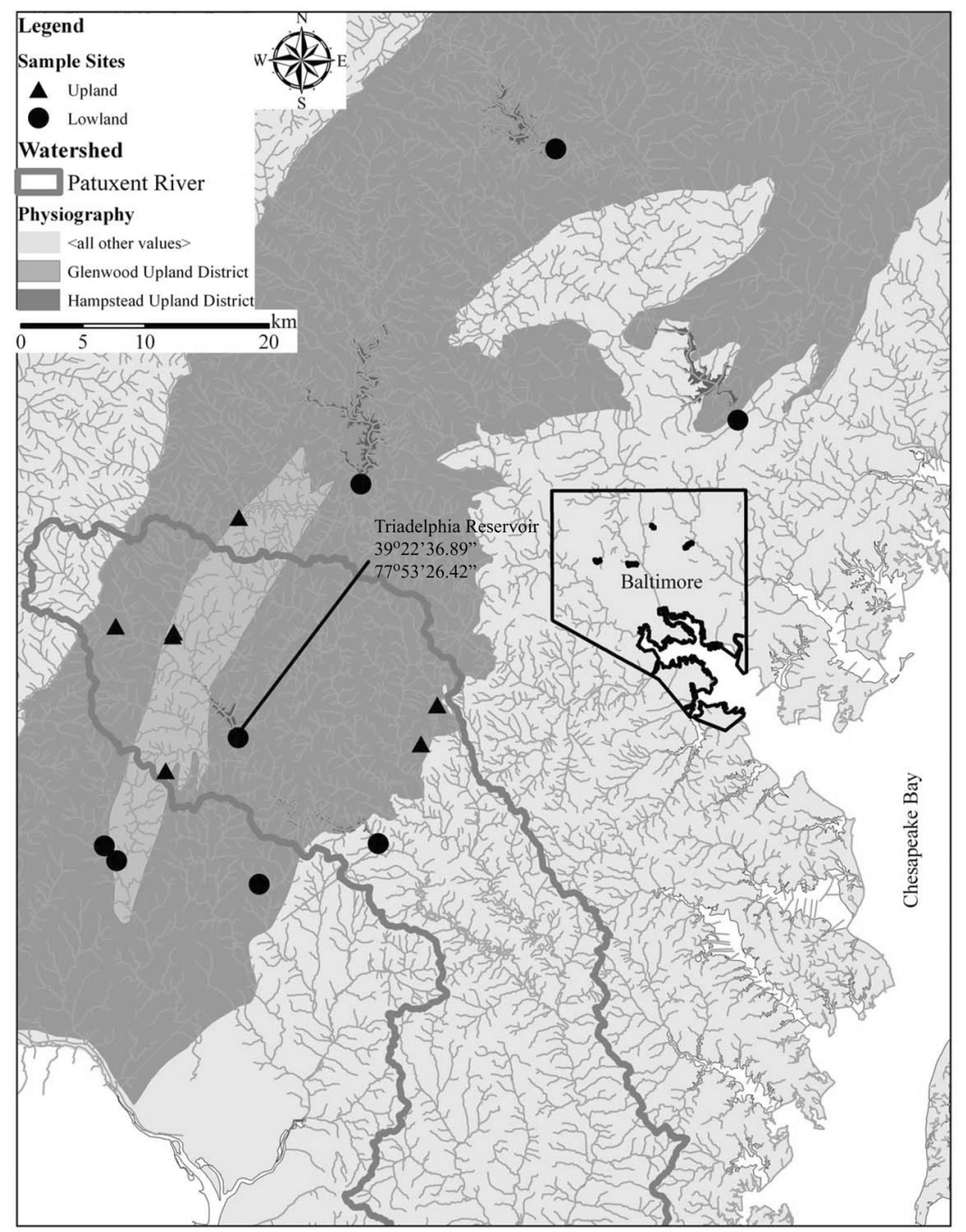

Figure 2. Physiographic districts and landform analysis study areas. Study areas were located in either upland (triangles) or lowland (circles) settings. 
ESTIMATOR software, and an HSPF watershed model [Cohn et al., 1989; Interstate Commission the Potomac River Basin (ICPRB), 2006].

The starting point for understanding sediment processes in the UPRW involved delineation of relevant landscape units and the channel network. Field observations and measurements were used to estimate sediment production rates for upland landscape units. Sediment yield for first-order watersheds was determined from accumulation in ponds. The subwatersheds selected for study in the UPRW and adjacent areas were dominated by one of the three land cover conditions typical of the region: suburban, agricultural, and forest. The measurements in the basins thereby provided an indication of sediment yield as a function of land cover. Sediment yield was upscaled based on the area of relevant landscape and land cover units, then evaluated against sediment accumulation in the Triadelphia Reservoir, as well as other large impoundments in similar physiographic settings.

\subsection{Landscape Delineation}

The study area and the entire UPRW lie within the delineated boundaries of two similar Piedmont subunits, the Hampstead Uplands District and the Glenwood Uplands District (Figure 2) [Reger and Cleaves, 2003]. Both districts have predominantly crystalline bedrock and modest relief of less than $100 \mathrm{~m}$, with exception of areas within the major fall zone gorges at the eastern boundary. We examined the portion of watersheds entirely upstream of the fall zone region.

Accounting for contributions to contemporary sediment yield requires accurate delineation of landforms relevant to the quantification of net erosion and storage in the landscape. The landscape was broadly divided into upland and lowland complexes [Cleaves, 1974]. Key objectives of the delineation were to define the location of (1) upland landform subunits with consistent controls, mechanisms, and rates of sediment production, (2) channel heads and, therefore, the extent of the channel network, and (3) the channel network transition from dominantly erosional (with little to no sediment storage) to alluvial with floodplain storage. Based on the typical observation that first-order channels generally do not have active floodplains, we broadly divided the landscape into upland and lowland landform units at the confluence of first-order and higher-order channels. The general landform partition conformed to the classification considered by previous investigations and has relevance to the dominance of erosion- or transport-limited conditions [Cleaves, 1974; Costa and Cleaves, 1984; Howard, 1999].

3.2.1. Uplands. Nearly balanced chemical weathering and mechanical erosion over the Quaternary Period pro- duced a dissected, dendritic tributary drainage network in upland portions of the Piedmont [Cleaves, 1974; Costa and Cleaves, 1984; Pavich, 1989]. However, increased rates of erosion from runoff over the past three centuries have substantially increased the rates of mechanical erosion relative to chemical weathering [Langland and Cronin, 2003]. Factors governing production and conveyance of runoff in the modern landscape play a key role in determining the magnitude and extent of continued dissection, the resulting sediment supply, and the transport efficiency within and from upland areas.

Upland landform subunits include hillslopes, hollows, and channels [Hack, 1960]. Hollows are vaguely defined but can be described as nonchanneled or zero-order upland valleys that form shallow concentrated surface runoff patterns in response to precipitation events. Sediment yield from these units was determined using field observations and eventbased flow and sediment monitoring. The yield from upland units is strongly influenced by both present and past land cover conditions. For example, reforested agricultural land can produce relatively large rates of overland flow and sediment transport that may be explained by the removal of surficial soil horizons, leaving less permeable soil at the ground surface [Costa, 1975]. First-order channels in forested and agricultural areas are often incised into in situ and colluvial material and show little evidence of alluvial deposition. Sediment yield from first-order basins can be estimated from both event-based flow and sediment monitoring and by measuring sediment accumulation in small ponds that are commonly constructed for agricultural uses, sediment control or storm water management.

3.2.2. Lowlands. The Piedmont above the fall zone contains large, low-gradient alluvial valleys. The common concavity of longitudinal river profiles and down-valley increase in cumulative valley flat area create conditions conducive to floodplain development [Hack, 1957; Bloom, 1998]. The net exchange of sediment between stream channels and floodplains depends, in part, on the space accommodation within alluvial valleys, as well as local base level controls provided by structures such as dams and culverts [Schenk and Hupp, 2009]. Flood magnitude and the elapsed time between major runoff events also influence sediment deposition and storage within valley networks [Wolman and Gerson, 1978].

3.2.3. Network geomorphology. Identification of the channel heads defining the upper limit of the stream network is necessary for reliable delineation of upland and lowland landforms and estimation of sediment storage associated with valley deposition. The $72 \mathrm{~km}^{2}$ fourth-order Cattail Creek subwatershed in the UPRW was selected as a focus 
for the evaluation. Channel heads were defined as the upstream limit of a persistent eroded channel. Their locations were identified using field and air photo reconnaissance. The mean drainage source area to channel initiation derived from the channel head data set was $0.15 \mathrm{~km}^{2}$.

Figure 3 shows portions of the derived Cattail Creek drainage network on a topographic map with $1.52 \mathrm{~m}(5 \mathrm{ft})$ contours. The channel heads are shown, as well as the channel network created using the mean channel initiation source area. Also shown is the extended tributary network derived using an initiation source area of $0.04 \mathrm{~km}^{2}$ that corresponded to the minimum source area measured in the channel head data set. The tributary network delineated by the dashed lines was much larger than the total length of the channel network, indicating the extent of shallow confined flow pathways in the landscape. The resulting map identifies the external tributary links within nonchanneled, zero-order upland valleys of the Piedmont, most of which are poorly documented in the spatial data layers commonly used by government agencies.

Results from the tributary network delineation provided a basis for estimating the relative extent of upland landform units. The minimum measured source area to channel initiation $\left(0.04 \mathrm{~km}^{2}\right)$ indicated that $35 \%$ of the Cattail Creek watershed was occupied by zero-order basins draining through nonchanneled upland valleys. The mean first-order basin area derived for the watershed was $0.3 \mathrm{~km}^{2}$, occupying $62 \%$ of the total drainage area (Figure 4 ). The lowlands that

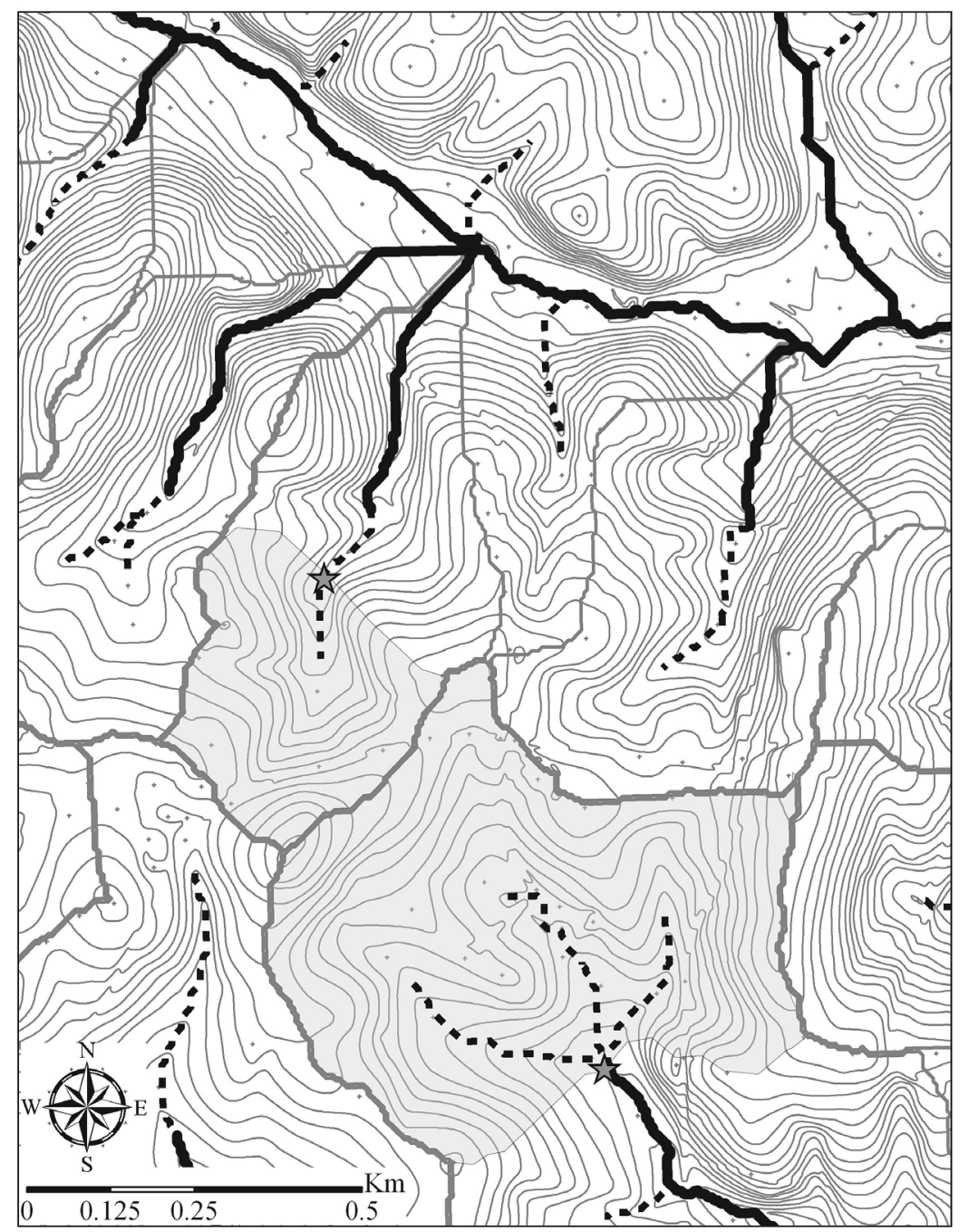

Figure 3. Channel head identification (stars), source area delineations (shaded), channels delineated using a $0.15 \mathrm{~km}^{2}$ source area (solid lines), and zero-order tributaries delineated using $0.04 \mathrm{~km}^{2}$ source areas (dashed lines). First-order basins are delineated by thick gray lines. Contours representing $1.52 \mathrm{~m}(5 \mathrm{ft})$ elevation intervals are shown by thin gray lines. 


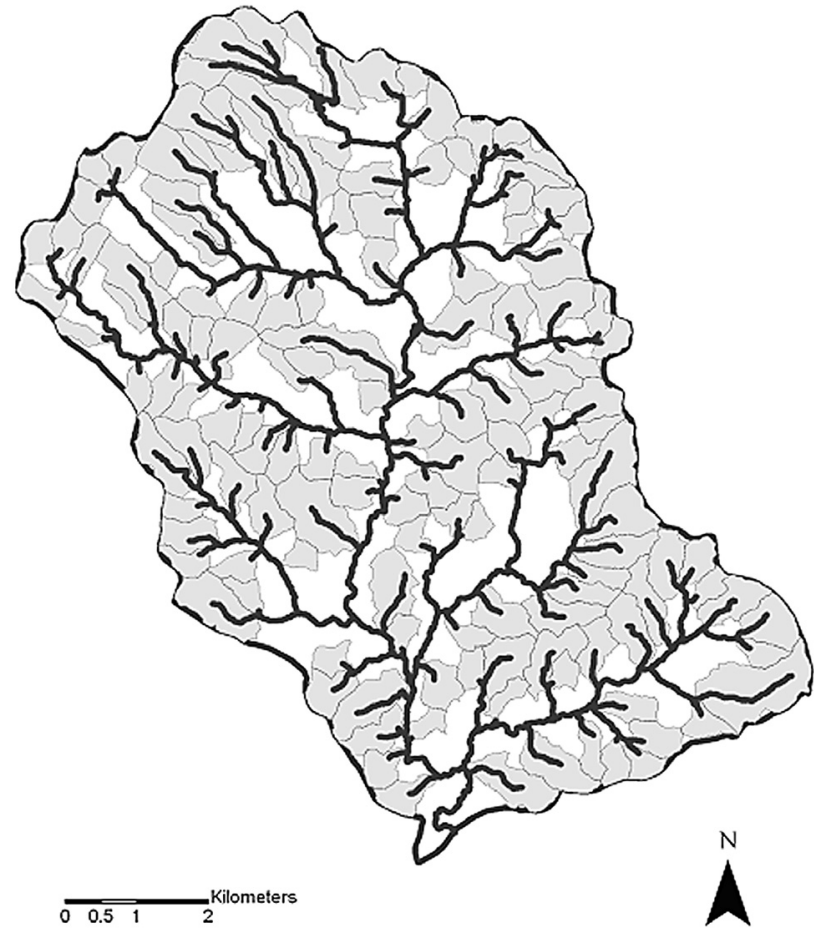

Figure 4. First-order channels and their respective basins (shaded) in the Cattail Creek watershed of the UPRW delineated using a source area to channel initiation of $0.15 \mathrm{~km}^{2}$.

receive input from the upland landforms and serve as locations for substantial sediment storage were estimated from available floodplain delineations (Howard County, Maryland floodplains - Vector digital data, Federal Emergency Management Agency, Washington, D. C., 1986, http://msc.fema. gov/webapp/wcs/stores/servlet/FemaWelcomeView?store $\mathrm{Id}=10001 \&$ catalogId=10001\&langId=-1). The mapped floodplains comprised approximately $3 \%$ of the Cattail Creek basin, which provided an indication of the relative extent of alluvial valley bottomland area in the Piedmont.

The morphometry of headwater drainage networks in the Piedmont exhibits a clear imprint from long-term weathering, landscape development, and mechanical erosion [Costa and Cleaves, 1984]. Zero-order tributaries can be difficult to delineate and morphologically altered by accumulations of agricultural sediment in topographic convergence zones [Costa, 1975]. The source area to channel initiation within the deposits varies with the land use history and direct alterations to upland drainage patterns. Colluvial deposits in upland valleys can create the appearance of alluvial floodplains in some upland basins. Channels can incise within the deposits, but lateral flows outward from the channel are usually minimal or do not occur because of the combined effects from enlarged channel capacity created from erosion and small contributing drainage areas. In some locations, remobilization of stored legacy sediment may be occurring via upstream propagation of channel incision through head cutting mechanisms at the upper termini of the first-order channel links.

The transition from dominantly erosional to storageexchange valley bottoms has not been clearly identified in most settings, including the Mid-Atlantic Piedmont. Alluvial floodplains typically become recognizable features along second- or third-order channels [Allmendinger et al., 2007]. Variations in the actual limits are strongly influenced by the history of upland sediment supply, watershed hydrology, valley profile, bedrock control, and artificial structures, including dams [Jain et al., 2008]. The reality that consistent metrics for floodplain delineation are unavailable requires that surrogates be employed for identifying the boundary between upland and lowland landforms. The computation of sediment yield over progressively larger spatial scales can serve as one such approach to determine where substantial alluvial storage and therefore floodplain development occurs in the contemporary landscape.

\subsection{Sediment Yield, Land Use, and Spatial Scales}

Sediment yield from different land uses and spatial scales in the Piedmont are shown in Figure 5, providing a basis for comparisons among the conditions characterizing the contemporary landscape. The higher stream orders on the $x$ axis correspond to larger watershed sizes [Dunne and Leopold, 1978]. Estimates for first-order basins were derived from sedimentation measurements in farm and storm water ponds [Verzstraeten and Poesen, 2001]. Each sampled basin was dominated by one of the three land cover types under consideration. Yield from third- and fifth-order watersheds was obtained from surveys of larger artificial lakes and water supply reservoirs, all of which received drainage from a mix of land uses [Gottschalk, 1948].

\subsubsection{Land use comparisons. Several trends were appar-} ent from the comparison of the geomorphic settings, land cover types, and spatial scales. Sediment yields from zeroorder basins were often much smaller than typical land cover specific EOF values from NRCS (data, 2007), indicating colluvial storage was occurring in zero-order basins. The yield from zero-order basins was smaller than from firstorder basins under similar forest and agricultural land cover conditions. This suggested that enlargement and extension of first-order channels played an important role in increasing upland sediment yield. These observations were supported by morphological evidence and precipitation event sampling in basins dominated by one of the three land cover types. 


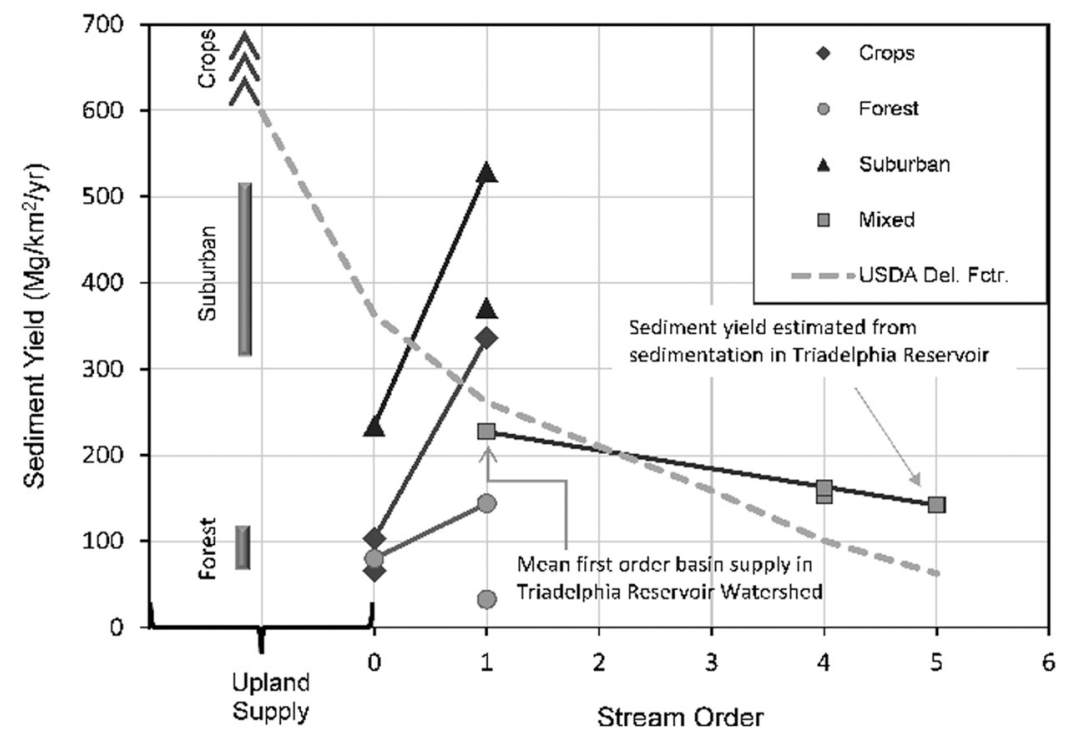

Figure 5. Sediment yield from flume, pond, and reservoir data plotted as a function of land cover and stream order. Lines connect observations within the same subbasin. Typical NRCS (data, 2007) upland erosion values are shown at left. Note that crop values are off the top of the chart. Sediment yield at the scale of zero-order basins was larger than upland supply when a substantial extent of the range of the NRCS values were considered, indicating upland storage. Yield from firstorder basins tended to be larger than the NRCS values, indicating net supply from first-order channel enlargement. Sediment yield decreased from first order to fifth order, indicating storage along the valley bottom of second- and higherorder channels. The USDA delivery factor, anchored at land use-weighted annual EOF value of $598 \mathrm{Mg} \mathrm{km}^{-2}[$ ICPRB, 2006], produced an inverse relation between sediment yield and drainage area at every spatial scale.

The upland basin comparisons clearly showed that sediment yield was influenced by land cover conditions. However, relative rankings of land use yield changed over the spatial scale range of the three Piedmont upland landform subunits considered. Hillslope sediment yield predicted by the NRCS (data, 2007) NRI database is smallest for forest and largest for cropped land, with suburban land use having intermediate values. The relative order of the land use trend was different at the scale of first-order basins, where yield values were smallest for forested conditions and largest for suburban land use, with agricultural watersheds having intermediate values.

The sediment yield from a first-order forested basin evaluated during the study was considerably larger than previously documented for small forested basins [Cleaves et al., 1970; Yorke and Herb, 1978; Patric et al., 1984]. This was attributed to several factors, the most apparent being active upland channel extension and enlargement. Another relevant process was observed further upslope within a nonchanneled upland valley. Field observations and storm runoff sampling within a measured forested basin revealed that commonly occurring overland flows were competent in their ability to move and imbricate gravel clasts within zero-order tributaries. Like much of Maryland's Piedmont, the basin had been cleared of trees and farmed over the past two centuries. The mobility of small gravel was unexpected, but conformed to suggestions by others that the erosion of permeable upper soil horizons and removal of organic matter has increased runoff and amplified erosion in the Piedmont uplands [Costa, 1975; Pavich, 1989].

The relatively large sediment yield measured in suburban first-order basins of the UPRW was intriguing because the development was completed decades ago, and it has been a commonly held view that urban areas become sediment starved following the period of initial construction [Smith et al., 2008]. Sediment yield derived from storm event sampling in a similarly mature suburban basin in the UPRW was also high relative to values reported in literature even though there were minimal opportunities for channel erosion. The cycle of sedimentation in urbanizing watersheds described by Wolman [1967] included reductions in sediment yield following urban development. However, it does not appear reasonable to assume that the sediment yield from mature urbanized areas can be exclusively attributed to channel enlargement based on the observations. Localized disturbances capable of generating elevated supplies of sediment offer an explanation for departures from the prediction. Wolman and Schick [1967] showed that construction sites can 
produce a very large yield of sediment compared to undisturbed landscapes in temperate humid environments. Modern sediment control technology has partly addressed this problem. However, sediment trapping efficiency has often been reported in the range of $50 \%$ to $75 \%$, allowing relatively large loads to occur during periods of construction [Schueler and Lugbill, 1990]. The areas under active construction at any one time period may be relatively small in an aging suburb. The combination of large unit sediment yield and small size of the areas under construction make the cumulative contributions especially dependent on the number of locations being disturbed and the effectiveness of mitigation measures.

3.3.2. Spatial scale comparisons. A comparison of upland sediment supply to the yield measured at Triadelphia Reservoir was made by weighting observed first- and zero-order basin yield values by the UPRW land cover composition (Table 1). The area of first-order basins was estimated using results from the Cattail Creek drainage network delineation. Zero-order basins draining directly to second-order or higher tributaries were estimated by subtraction of the first-order basin and mapped floodplain areas from the total area of the UPRW. The approach thereby accounted for the contributions from nonchanneled and channeled uplands. Sediment contributions from construction were calculated based on average annual estimates of development activity over the lifespan of the reservoir. Results from the analysis were consistent with the commonly described trend of decreasing yield with increasing drainage area. The yield comparison indicated that second- to fifth-order valleys have stored more than one third of the upland sediment supply over the recent half century time period considered by the evaluation.

Although the comparison of first- and fifth-order basins in Figure 5 and Table 1 predicted a net reduction in sediment yield with increasing drainage area, examination at a finer

Table 1. Sediment Yield Estimates for the Upper Patuxent River Watershed

\begin{tabular}{lcc}
\hline Land Use & $\begin{array}{c}\text { Drainage } \\
\text { Area }(\%)\end{array}$ & $\begin{array}{c}\text { Sediment Yield } \\
\left(\mathrm{Mg} \mathrm{km}^{-2} \mathrm{yr}^{-1}\right)\end{array}$ \\
\hline Agricultural & 52 & 336 \\
Forest & 33 & 125 \\
Urban $_{\text {Construction }}^{\mathrm{a}}$ & 15 & 450 \\
Weighted upland area average $^{\mathrm{b}}$ & 0.2 & 2102 \\
Fifth-order reservoir & & 227 \\
\hline
\end{tabular}

${ }^{\mathrm{a}}$ Construction yield assumed $75 \%$ efficiency for sediment control measures.

${ }^{b}$ Weighted by land use and proportion of the UPRW composed of zero- and first-order basins draining to valleys with second- or higher-order tributaries. resolution produced a more complex pattern that has important implications for targeting of locations to address watershed sediment problems. Most notably, event sampling within upland landform units in the UPRW indicated that sediment yield can increase with drainage area through upland portions of the watershed, reaching a maximum at the outlet of first-order basins. A "local" sediment yield ratio $\left(\mathrm{SYR}_{n}\right)$ defined as

$$
\mathrm{SYR}_{n}=\frac{\mathrm{SY}_{n}}{\mathrm{SY}_{n-1}}
$$

where SY is sediment yield and $n$ is stream order can highlight where net additions from erosion or subtractions from sediment storage occur. A value exceeding unity is produced where sediment yield at the lower boundary of a landform subunit, expressed in the numerator, is higher than at the upper boundary expressed in the denominator. Tributary erosion is the common cause of such a result. $\mathrm{A} \mathrm{SYR}_{n}$ value less than unity is produced where sediment yield is larger at the upper boundary and internal sediment storage has occurred within the landform subunit under consideration.

Multiple factors influence spatial and temporal SYR trends within a watershed. Previous investigations showing varied rates of regolith development in the Piedmont suggest that background upland SYR values are strongly influenced by lithology [Cleaves et al., 1974; Costa and Cleaves, 1984; Pavich, 1989]. Limiting the range of lithology conditions compared in this study was an important consideration for that reason. The trends in Figure 5 indicated that land cover can also influence the ratio and that wide variations in the relation are likely within the generalized upland land use categories.

Land cover and management conditions can vary considerably within both suburban and rural headwater areas. EOF sediment yield predicted by the NRCS (data, 2007) NRI database can be relatively large in rural areas, particularly for agricultural land uses. Locations characterized by high rates of hillslope sediment supply and inadequate transport capacity within downslope upland valleys produce sediment storage and a yield ratio less than the unity condition, $\mathrm{SYR}_{0}$ $<1$. Ratios can also be below unity where sediment best management practices have been successfully deployed. For example, the sediment yield from agricultural fields can be substantially reduced where grassed buffer strips are in place and where zero-order tributaries are maintained as "grassed waterways." Conversely, augmentation of upland sediment supply can occur where shallow concentrated surface flows frequently form on exposed soil during periods of rainfall runoff in upland valleys, producing $\mathrm{SYR}_{0}>1$ as a result of upland valley erosion. Such conditions occur in suburban 
areas experiencing storm water infrastructure problems, poorly managed agricultural drainage conveyances, and in forested zero-order tributaries affected by the legacy effects of intense farming activities.

The link between upland sediment production and yield is clearly not a simple one, but worthy of close attention to identify the sources influencing the sediment loads from large watersheds. Once in the channel network, SYR values change considerably with increasing scale from first- to higherorder channels. Figure 5 provides evidence that channel erosion augments upland hillslope sediment supply, as shown by the yield increases over the scale change from zero- to first-order basins in the plot. There was a consistent pattern of $\mathrm{SYR}_{1}>1$ in the UPRW, which indicated that additional sediment was being produced in upland channels regardless of the current land use. The downstream SYR trend was reversed only within larger valleys with sufficient space to store the upland sediment in alluvial floodplain deposits.

At watershed scales larger than the area of first-order basins, land cover is most often mixed, and the sediment yield reported is usually a weighted average for all of the contributing land cover conditions. SYR ${ }_{3+}$ values in settings sampled in Maryland's Piedmont were generally less than unity, indicating net sediment storage over the decadal time scale evaluated. It is important to consider that localized reaches of alluvial valleys have the capacity to augment the sediment supply, particularly where historic accumulations of sediment are in the process of being reworked under the influence of altered hydrologic regimes [Jacobsen and Coleman, 1986; Schenk and Hupp, 2009; Walter and Merritts, 2008; Smith et al., 2008]. Even with the known existence of those processes, the net contribution calculated for the UPRW alluvial valley network was one of sediment storage over decadal time scales. The timing and rate of valley sediment evacuation is governed by the occurrence of relatively large runoff events, complicating predictions over time scales of less than a decade [Wolman and Gerson, 1978].

It is readily apparent from the comparison in Figure 5 that changes in sediment yield with spatial scale can differ from the simple inverse trend given by the USDA delivery factor. Most notably, the delivery factor predicts that sediment storage exceeds supply within the upland portions of the landscape. Although sediment storage can dominate between EOF and the outlet of zero-order basins $\left(\mathrm{SYR}_{0}<1\right)$, conditions causing hillslope sediment supply to be augmented by upland valley erosion can occur in all contemporary Piedmont land cover conditions, including forests. The consistently observed $\mathrm{SYR}_{1}>1$ trend suggested that channel erosion was a substantial contributor to the total upland sediment yield to alluvial valleys. A likely culprit associated with upland tributary erosion in the contemporary landscape was increased runoff resulting from past and present land alterations.

The intention of the landform SYR calculations from the UPRW data was to account for net sediment supply and storage in defined upland and lowland settings. Framing the application of SYR values relative to geomorphic setting, lithology, and land use provided a useful basis for interpreting sediment yield calculations. Adjustments to upland valley geomorphic conditions are partly dependent on the water and sediment supply from upstream hillslopes. SYR values provided an index of the ability of a tributary reach to pass the supplied load. Despite the utility of the ratio, caution is necessary when applying SYR values to a range of EOF yield conditions that are estimated rather than predicted.

The SYR trends in the UPRW imply that the net effect of sediment management investments such as stream stabilization on the watershed sediment yield depends on the condition and location of the settings selected for the interventions. Sediment processes at different spatial scales are unlikely to be properly represented by the USDA delivery factor, particularly in upland areas where zero- and first-order tributaries influence the net sediment supply to alluvial valleys. Drainage network simulations that include only third and higher tributaries present substantial limitations because of the potential for substantial sediment contributions from headwater tributary erosion. The complex relations between EOF values and the upstream limit of the modeled watershed cannot be reliably estimated using a simple delivery factor. Landform-specific observations and multiple lines of evidence are needed to locate and estimate sediment sources at the scale of low-order basins. This must involve consideration of the cumulative hydrologic and hydraulic effects from lithology, land use, and watershed history.

\section{SEDIMENT YIELD IN THE MINNESOTA RIVER BASIN}

\subsection{Site Description}

The Le Sueur River drains a $2880 \mathrm{~km}^{2}$ watershed in south central Minnesota, joining the Blue Earth River just before draining into the Minnesota River (Figure 6). Although relief in most of the watershed is very small, the surficial geology and river longitudinal profiles clearly indicate that this has been an active and dynamic landscape over the past few millennia.

This part of south central Minnesota was deglaciated approximately 14,000 radiocarbon years before present (rcybp) when the Des Moines lobe of the Laurentide Ice Sheet retreated, leaving behind a relatively flat terrain 


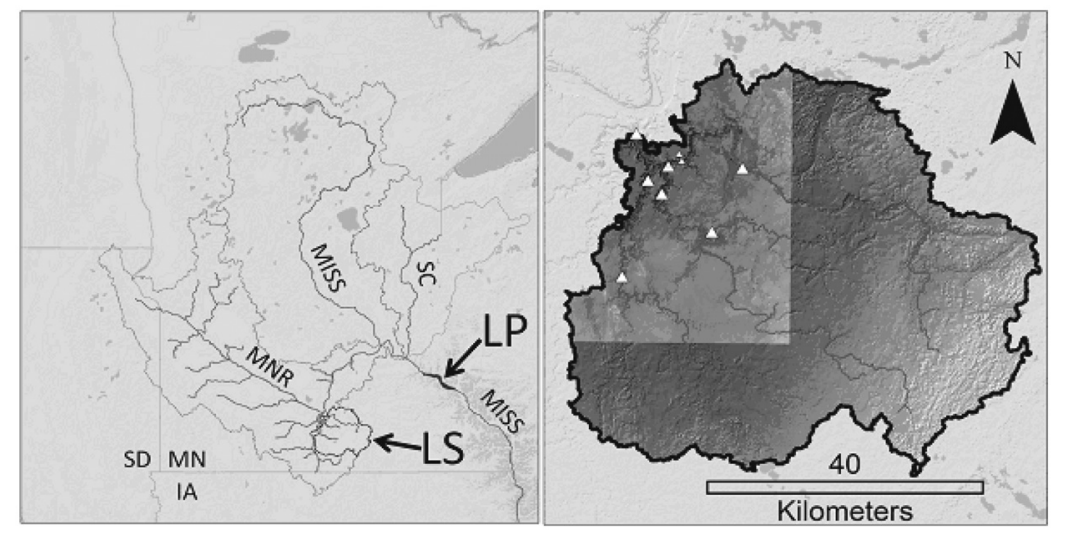

Figure 6. Location of the Le Sueur watershed (LS), south central Minnesota (MN), and Lake Pepin (LP) on the Mississippi River (MISS) in southeastern Minnesota. Also shown are the Minnesota (MNR) and St. Croix (SC) rivers. Triangles in the right panel indicate the locations of gauging stations on the main stems (large) and ravines (small). The lighter grayscale portion in the northwest corner of the Le Sueur watershed DEM shows the extent of lidar data. Mouth of Le Sueur watershed is located at $44^{\circ} 07^{\prime} 36^{\prime \prime} \mathrm{N}, 94^{\circ} 02^{\prime} 52^{\prime \prime} \mathrm{W}$.

underlain by a $50-60 \mathrm{~m}$ thick package of interbedded finegrained (65\% silt and clay) till and glaciofluvial sand strata. The southern and western half of the watershed comprised Glacial Lake Minnesota for several millennia, leaving behind a thin mantle of lacustrine deposits in that part of the basin [Thorleifson, 1996]. Throughout the watershed, remnants of the active late Pleistocene history can be found, including large subglacial and proglacial channels, large meltwater lakes, small kettle lakes, and stagnant ice moraines [Jennings, 2010].

Approximately 13,400 years before present $(11,500$ rcybp), Glacial Lake Agassiz drained through the Minnesota River, causing as much as $70 \mathrm{~m}$ of incision near the confluence with the Blue Earth River [Clayton and Moran, 1982; Matsch, 1983; Gran et al., 2009]. In response to the base level fall, the Blue Earth and Le Sueur systems began incising rapidly causing a knickpoint that has propagated $40 \mathrm{~km}$ up through the Le Sueur network [Belmont, 2011]. Throughout much of the Holocene, the watershed contained many internally drained wetlands and lakes and a fragmented stream network, which presumably developed better connectivity over time, particularly with the passage of the knickpoint in the lower reaches.

European-style agriculture began circa 1830, initially draining wetlands and clearing forest and prairie to plant a diversity of crops. In the past few decades, nearly all arable land is in row crop production (primarily corn and soybean), with narrow grass and forest buffers lining streams. For agricultural purposes, the fine-grained soils require tillage, and the thermal regime (with freezing temperatures occurring as late as May) deters use of cover crops that would otherwise reduce erosion in the spring.
In addition to clearing vegetation and tilling the soil, agriculture has profoundly changed the watershed hydrology in several significant ways. The vegetation change and bare spring soils have reduced evapotranspiration. Ditches throughout the watershed have greatly increased hydrologic connectivity and effectively increased the drainage area. In addition, subsurface tile drainage has been introduced, initially as ceramic pipes and more recently as plastic corrugated tubing buried various depths below the plow line, to increase runoff efficiency. The extent and density of drain tiles is not well documented, but artificial drainage appears to be nearly ubiquitous, with spacing between tiles as close as $15-20 \mathrm{~m}$. The hydrologic effects of these drain tiles are generally understood, but quantitative models have struggled to accurately predict drain tile effects under the wide range of environmental conditions that exist [Blann et al., 2009]. In terms of sediment dynamics, it is expected that drain tiles have both positive and negative impacts.

Detrimental impacts of excessive sedimentation throughout the Minnesota River Basin, and specifically in the Le Sueur River, are well documented [Minnesota Pollution Control Agency, 2008]. The problem is pervasive, with many reaches of the Minnesota and Le Sueur Rivers listed as impaired under the Clean Water Act (1972). Similar scenarios have been described in agricultural landscapes throughout the Midwestern United States and elsewhere [Hooke, 2000; Montgomery, 2007], but the south central Minnesota landscape appears to be particularly sensitive. Sedimentary records from Lake Pepin, a naturally dammed lake on the Mississippi River downstream from the confluence with the Minnesota River, indicate that the Minnesota River has been the dominant sediment source throughout the Holocene and 
that sediment delivery from the Minnesota River basin has increased tenfold since the mid-1800s [Kelley and Nater, 2000; Engstrom et al., 2009].

A broad effort is underway to improve water quality in Minnesota. In 2008, state taxpayers approved an amendment to the state constitution to increase sales tax for the exclusive purpose of protecting and restoring water, wildlife, and cultural resources. The amendment is expected to generate over $\$ 150$ million in tax revenue per year, providing an extraordinary opportunity and a compelling obligation to effectively implement watershed rehabilitation and restoration. Reducing sediment loading to the Minnesota River and Lake Pepin are primary objectives for restoring clean water and improving the ecosystem. The Le Sueur accounts for a significant part of the problem, contributing as much as one third of the Minnesota River suspended sediment load, while comprising only $7 \%$ of the watershed area [Wilcock, 2009].

Developing an effective sediment reduction strategy for the Le Sueur drainage basin requires explicit consideration for the location, mechanisms, and rates of sediment sources and sinks throughout the watershed. Implementing such a strategy requires additional economic and social considerations that will not be considered here.

\subsection{Landscape Delineation and Constraints on Rates and Mechanisms}

As is the case for the Maryland Piedmont, an estimate of sediment supply and yield must begin with the delineation of landscape units and their rates of sediment production and storage. The morphological conditions and processes in the Le Sueur watershed require a different mix of techniques to delineate landscape elements and constrain rates. Consistent with the above, we delineate sediment sources and sinks and identify a critical transition between alluvial and erosional portions of the landscape. However, the alluvial portion of the channel network upstream from the knickpoint is also upstream of the primarily erosional portion of the channel network associated with the knick zone in the case of the Le Sueur.

Three primary sediment sources exist in the Le Sueur watershed: uplands, bluffs, and ravines (Figure 7). Floodplains and stream banks are inherently exchange landforms, serving as both sediment sources and sinks. They represent an important challenge for developing sediment budgets and are considered separately in the next section.

High-resolution topographic data and spatial data analysis software currently allow the location and morphology of sediment sources to be defined with a precision not previously available. Constraining erosion rates from these landform units and determining the fate of the eroded sediment

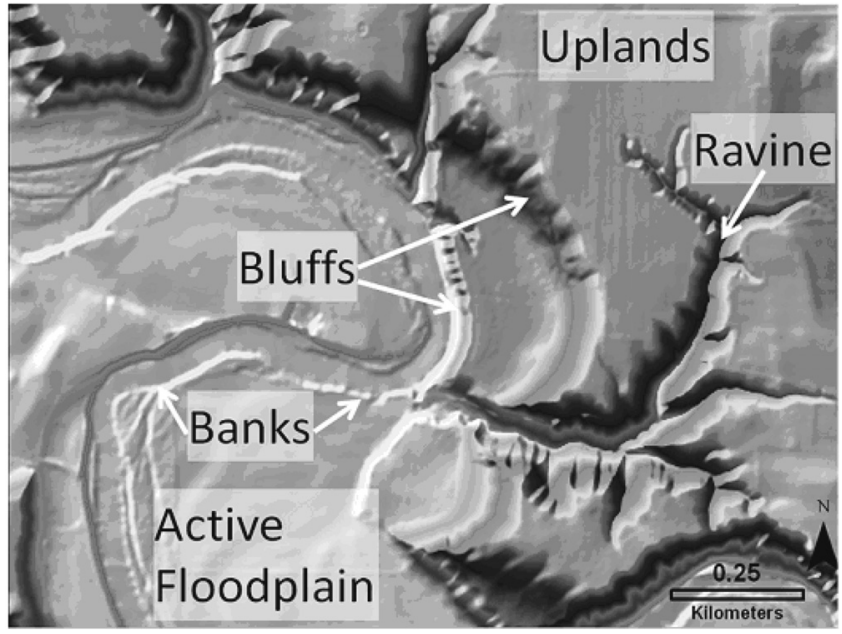

Figure 7. Sediment sources and sinks in the Le Sueur watershed including flat agricultural uplands, ravines, bluffs (shown is a $27 \mathrm{~m}$ tall bluff connected to river and $40 \mathrm{~m}$ tall paleobluff separated from the river by a fluvial terrace), banks, and active floodplain.

remains a considerable challenge. Generating accurate estimates of erosion requires a combination of targeted measurements and reasonable assumptions. This section discusses the techniques used and challenges encountered in constraining the locations, mechanisms, and rates associated with sediment sources throughout the watershed.

More than $90 \%$ of the vast, flat uplands in the Le Sueur watershed are used for row crop production. Processes of erosion in the uplands include sheet and rill erosion, gully development, and enlargement of drainage ditches. But the rates at which these processes actually convey sediment to the channel are difficult to constrain due to extraordinary spatial heterogeneity and temporal variability. Upland erosion estimates computed from the USLE [Wischmeier and Smith, 1978], or its derivatives, modified USLE [Williams, 1975] and revised USLE [Renard et al., 1997], must be viewed skeptically in this landscape for two reasons. First, surface erosion is highly sensitive to the threshold at which surface runoff occurs, which cannot currently be predicted with accuracy in this artificially drained landscape. Second, a relatively wide range of sediment delivery ratios likely exists, driven by relatively subtle topographic features. This causes large uncertainty in sediment delivery, which is especially problematic because the source area is so large.

Bluffs are tall, near-vertical features that exist almost exclusively within the knick zone of the Le Sueur (see Figure $8)$. They are primarily composed of glacial sediments and can be very large, ( $>50 \mathrm{~m}$ high and hundreds of meters long) or relatively small ( $3 \mathrm{~m}$ high and $<10 \mathrm{~m}$ long). Some bluffs are directly connected to the river. Others were previously 


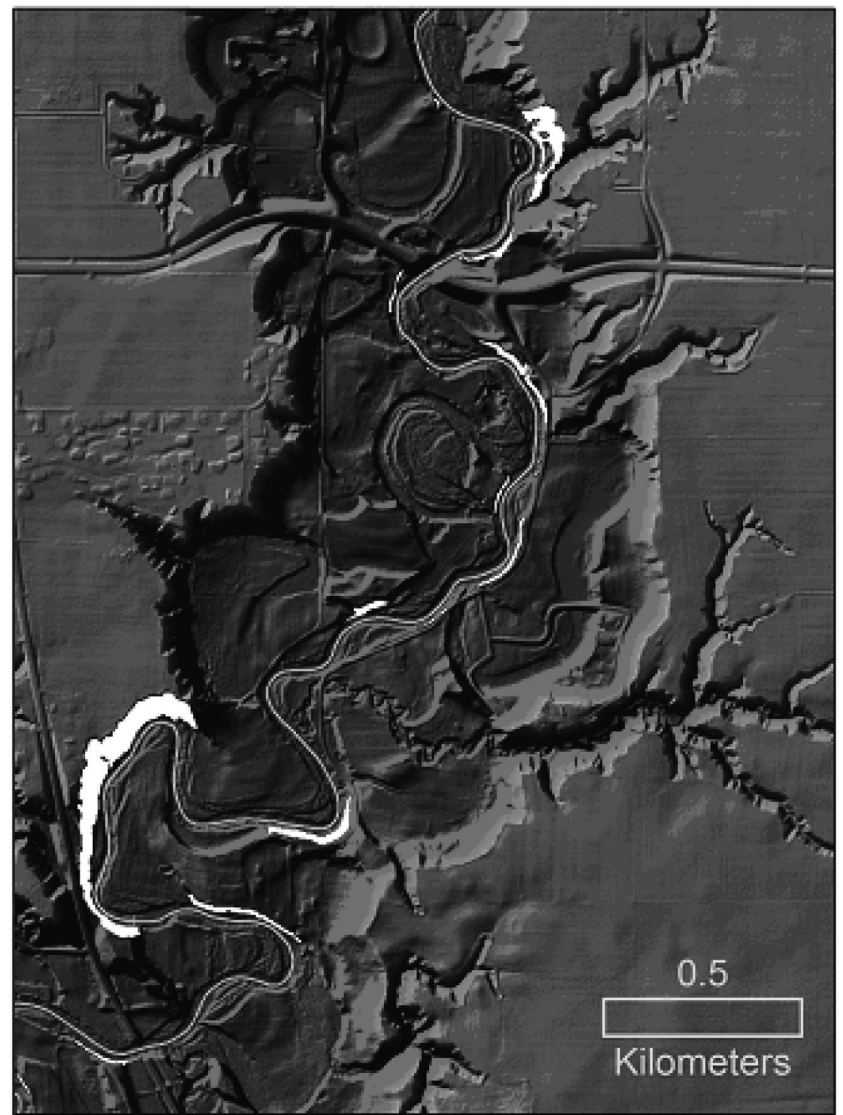

Figure 8. Bluffs (in white) along the main stem of the Le Sueur River automatically delineated using neighborhood analysis (focal range) as described in text.

connected to the river, but the river has since migrated away and incised, leaving them stranded behind as strath terraces. Identification of bluffs is relatively straightforward using a simple algorithm that extracts cells based on a local relief threshold (e.g., $3 \mathrm{~m}$ of relief within a $9 \mathrm{~m}$ by $9 \mathrm{~m}$ neighborhood, Figure 8), but measuring meaningful erosion rates is challenging.

Bluff erosion is driven by fluvial undercutting at the toe, which triggers slope failure. The rate of erosion is influenced by physical properties of the layered glacial material of which they are composed, including cohesive strength, hydraulic conductivity, vegetation, and moisture content. In theory, bluff erosion rates could be modeled from hydrology, geotechnical properties [Simon et al., 2000], and vegetation effects [Simon and Collison, 2002; Bankhead and Simon, 2010], but upscaling from a few bluffs on which measurements can reasonably be made to all $(300+)$ bluffs throughout the watershed is confounded by the spatial heterogeneity of glacial deposits.
Bluff erosion rates can be directly measured from historic air photos, comparing bluff crests over multiple decades. Such erosion rates are defined for the time scale over which they are measured and may or may not be applicable to shorter or longer time scales. In addition, careful consideration of bluff retreat processes and geometry are needed to determine sediment supply. Over century times scales, the crest and toe of the bluffs can be assumed to retreat in parallel, as long as they remain connected to the primary driver of erosion, the river. However, over shorter time scales, the rate of sediment supply can be smaller if the bluff crest retreats more rapidly than its toe, with a minimum obtained if the toe erosion rate is zero. A bluff erosion rate for the Le Sueur was developed by combining estimates of bluff crest erosion rate with bluff toe erosion rates determined from channel migration measured separately.

Bluff erosion rates can also be measured utilizing groundbased surface elevation scanning technology. The precision of these instruments (less than $1 \mathrm{~cm}$ ) provides an extraordinary opportunity to directly measure erosion on annual or subannual time scales, but a number of logistical complications must be overcome, and ultimately, multiyear erosion rates measured on a few bluffs must be extrapolated to all other bluffs throughout the system. Selecting sites that cover the full range of bluff types in terms of size, composition, aspect, and proximity to roads is critical for upscaling in a process-sensitive manner (see S. S. Day et al. (Change detection on bluffs using terrestrial laser mapping technology, submitted to Earth Surface Processes and Landforms, 2010) for detailed discussion).

Ravines are small, steep channel networks primarily found in the incised portion of the basin, connecting the broad, flat uplands to the incised Le Sueur river channel. These features can easily be identified and delineated from high-resolution topography data [Wing, 2009]. Constraining accurate sediment contributions from ravines is challenging because they erode by a combination of hillslope and fluvial processes. In addition, ravines can serve as sediment sinks, storing significant amounts of sediment behind landslides and woody debris jams. Such fine-scale sediment storage and release processes are not easily predicted from topography data alone, but field observations indicate that fill terraces can dominate the sediment contributions from some ravines. Release of stored sediment from ravines can be exacerbated under conditions where precipitation is increasing or flow is being concentrated in the ravines by artificial drainage of the uplands.

Erosion in ravines is ultimately driven by fluvial incision and subsequent undercutting, hillslope creep, or mass wasting. Measuring sediment yield from ravines is challenging because of the flashy nature of these systems. Samples collected from a dozen events in a few (two to four) ravines 
between 2008 and 2010 indicate that most sediment is transported through these systems in a matter of hours, and sediment is only mobilized during relatively large precipitation events (K. Gran, personal communication, 2010). Extrapolating sediment yields from a few ravines to the more than 100 ravines found throughout the Le Sueur watershed is problematic considering the great diversity in ravine size, shape, relief, etc. In addition, sediment export from these systems is likely to be highly nonlinear as a function of runoff, so it is essential that ravines are monitored over a wide range of environmental conditions before proper constraints can be made.

\subsection{Sediment Storage in the Uplands and Fluvial Network}

An enduring problem in geomorphology is the understanding and prediction of the mechanisms, rates, and timing of sediment storage in the landscape [Trimble, 1977; Wolman, 1977; Walling, 1983]. The Le Sueur watershed provides a relatively unique opportunity to study sediment storage. Above the knick zone, sediment storage is widely distributed and spatially complex, representative of flat, agricultural landscapes that dominate the Midwestern United States. Within the knick zone, sediment transport and storage processes are dominated by adjustments within a steep, rapidly incising valley.

There is abundant evidence that a significant portion of sediment eroded from fields is deposited before reaching the river network. In the Le Sueur, field evidence of eroded sediment that remains stored within the landscape includes deposits of windblown sediment less than a few centimeters thick on snow patches every spring. In addition, some agricultural fields that are apparently subjected to strong winds have been observed to produce "mud dunes" as high as a meter at the edge of fields where vegetation provides the necessary roughness to trap windblown sediment.

Evidence for sediment storage within the landscape has been observed in many watersheds covering a wide range of tectonic and climatic environments [Costa, 1975; Meade, 1982; Phillips, 1991; Trimble, 1999; Bierman et al., 2005]. However, actually quantifying the location, mechanism, volume, and duration of storage within the landscape is difficult within heavily modified agricultural settings. De Alba [2001] developed and applied a numerical model to quantify the amount of soil redistribution that can be attributed to tillage. Such models make predictions that can be field tested, but they are difficult to apply at the watershed scale. The relevance of such models depends on whether or not human dynamics can be adequately captured. This modeling problem is common to heavily engineered landscapes, as discussed above in the context of construction sites in the UPRW.
Sediment storage in valley bottoms is more spatially focused than upland storage. Nevertheless, the Le Sueur channel network exemplifies some of the challenges for making meaningful estimates of sediment storage in the channel and floodplain. One complication arises from the nonuniform structure of the stream network. The "natural" channel network of the Le Sueur, not including human-engineered ditches, includes four Strahler [1957] stream orders. However, the notion of stream order loses some meaning in the relatively flat, human-modified landscape. For example, first-order streams exhibit a wide range of contributing drainage areas $\left(<1\right.$ to $\left.217 \mathrm{~km}^{2}\right)$, due in part to the once-internally drained areas that have been connected to the channel network either naturally or by humans using surface ditches or subsurface drain tiles. The total length of agricultural drainage ditches is over $450 \mathrm{~km}$, comprising nearly a quarter of the total surface drainage network.

A more meaningful way to categorize the network is in terms of sediment storage and transport dynamics, as discussed for the UPRW. According to this categorization, the Le Sueur drainage network can be separated into four distinct types, low-gradient agricultural ditches, low-gradient natural channels above the knickpoint (average slope is 0.0004), high-gradient main stem channels within the knick zone (slope is 0.002), and high-gradient, mostly ephemeral ravines that connect the uplands to the incised river, primarily within the knick zone. Each of these distinct channel types plays a potentially important role in establishing sediment sources and sinks and exhibits different challenges in determining rates of sediment storage over annual to decadal time scales.

The ditches are generally straight channels with $45^{\circ}$ grassed side slopes. Despite the apparent uniformity in planform, these human-designed features exhibit remarkable diversity in sediment transport rates. Many serve as sediment sinks for silt and clay, while others actively transport fine gravel. Ditches are "cleaned" as needed, typically once every 10 to 50 years, but the criteria used to determine when ditches need cleaning are rather arbitrary. Sediment excavated from the ditch is typically placed back on the levee of the ditch, or back on the adjacent agricultural field, and the amount of sediment removed is not documented (C. Austinson, Blue Earth County Ditch Manager, personal communication, 2009). For these reasons, ditches are challenging systems to incorporate into a sediment budget or routing model.

Most of the agricultural ditches drain to low-gradient natural channels, which define the Le Sueur network above the knick zone. These channels migrate laterally, but at a relatively slow pace $\left(<10 \mathrm{~cm} \mathrm{yr}^{-1}\right.$ on average), and maintain a floodplain by lateral and vertical accretion. Floodplains represent a large potential source of sediment directly accessible to the channel, but accounting for net exchange of sediment 
between the channel and floodplain requires consideration of both erosion and deposition. Erosional processes include bank retreat, channel widening, and vertical incision. Depositional processes include point bar deposition and overbank deposition.

The effort required to measure the actual fluxes of sediment in and out of the floodplain can be considerable, but is necessary in systems for which substantial valley bottom storage is indicated [Walling, 1999]. Basic geomorphic observations may be sufficient to indicate whether a floodplain system is aggrading or degrading in some cases. Generally speaking, in a net aggradational environment, the floodplain should be accessed frequently by the river, and deposition from large events should be measurable. Topographic lows in the floodplain, such as cutoff channels, should not persist for long periods of time. In contrast, key morphological indicators of net floodplain degradation include entrenchment of the channel or systematic differences in floodplain elevation on either side of the channel, such that cut banks are significantly taller than depositing banks [Lauer and Parker, 2008a, 2008b]. In addition, changes in channel width can be used to estimate net storage or evacuation of sediment from the floodplains [Dean and Schmidt, 2011].

The floodplains associated with the low-gradient, natural channels of the Le Sueur river network appear to be near a state of mass flux equilibrium with no signs of systematic floodplain aggradation or degradation in the recent past. To quantitatively test this observation, we used the Planform Statistics Tool (available from the National Center for Earthsurface Dynamics Stream Restoration Toolbox, http://www. nced.umn.edu/content/tools-and-data) to estimate net erosion that has resulted from channel migration between 1938 and 2005. This tool computes migration distance at userspecified intervals along the river (every $10 \mathrm{~m}$ in this study) between two points in time. The tool also extracts bank elevations at each node from high-resolution ground elevation data and combines the migration rate with the difference in bank elevation to compute local, net sediment contributions from stream banks [Lauer and Parker, 2008a].

The approach described above primarily accounts for floodplain deposition by lateral accretion, but vertical accretion from overbank deposition must also be considered. In the simplest form, overbank deposition can be modeled as the product of floodplain discharge and suspended sediment concentration. A trapping efficiency can be empirically calibrated and is expected to change as a function of vegetation and suspended sediment grain size. Concentration can vary by several orders of magnitude over the course of individual storm hydrographs and varies significantly from event to event, which becomes a significant problem when direct observations are few in number.
Floodplain vegetation poses two additional problems. For one, dense vegetation in floodplains is often not adequately filtered out in the process of generating a bare-earth digital elevation model (DEM), resulting in an inaccurate surface. The vegetation also influences the hydraulic conditions and sediment dynamics. For some floodplain environments, vegetation can be treated as relatively static, with a single trapping efficiency over time. In other floodplain environments, an understanding of seasonal growth patterns must be coupled with flow data. The field of ecohydraulics is currently making important gains in modeling the hydraulic implications of vegetation, but much work remains before reliable network-scale models are available [Perona et al., 2009; Corenblit et al., 2009].

Even when this suite of information is available, the challenge of predicting overbank deposition is formidable. In addition to knowing the concentration of sediment in transport, deposition is mediated by the grain size distribution of suspended sediment, which may change considerably over the course of a flow event. Instruments that measure sediment concentration and grain size distribution are helpful for constraining this problem, but cost and logistical complications preclude their use for constraining network-scale grain size dynamics.

Hydrologic analysis indicates that high flows in the Le Sueur are increasing in frequency and magnitude [Novotny and Stefan, 2007]. Field observations suggest that the increases are causing channel widening throughout much of the channel network. To account for the amount of sediment contributed from banks and floodplains via channel widening, we measured channel width from historic air photos at multiple times between 1938 and 2005. Accurate estimates of channel width were obtained by manually delineating polygons (each 500 to $1000 \mathrm{~m}$ long) outlining the active channel and dividing by length. The net contribution of sediment from channel widening was then computed as the product of the change in channel width, average channel depth, and the length of channel that has experienced channel widening.

In the Le Sueur channel network, the calculations above provide reasonable constraints on the amount of sediment derived from widening and meander migration. However, neither of these approaches account for sediment storage and erosion related to large woody debris jams, which occur in the low-gradient natural channels at a frequency of approximately once every $2 \mathrm{~km}$. Our field observations indicate that erosion and deposition are approximately balanced in the vicinity of debris jams, although more detailed surveying would be needed to confirm this. Given the sparse number of debris jams, the apparent balance between erosion and deposition, and absence of detailed information, no source or 
sink of sediment from debris jams was included in the budget.

The relatively high-gradient main stem channels within the knick zone of the Le Sueur exhibit transport and storage dynamics that are substantially different from the low-gradient channels discussed above, similar to but in reverse order to the channel network of the UPRW. Meander migration rates within the knick zone are relatively high $(20-30 \mathrm{~cm}$ $\mathrm{yr}^{-1}$ ) according to historic air photo analyses. This is due in part to the dramatic increases in sediment loading within the knick zone (see Table 2) and significant increase in the caliber of sediment contributed as gravel and boulders are eroded from bluffs, terraces, and ravines. Relatively rapid vertical incision of the river, currently and throughout the Holocene, causes floodplains to be abandoned. Strath terraces that are preserved throughout the incised river valley are exceptionally uniform in thickness, between 2 and $3 \mathrm{~m}$ with a thin base of gravel, a relatively thick package of laterally accreted sand and mud capped by a variable, but typically thin mantle of fine-grained overbank deposits. These terrace deposits represent net long-term storage within the knick zone, but the volume stored is relatively small compared with the volume that has been removed over the course of the Holocene.

The morphology of the modern floodplain through the knick zone is strongly controlled by Holocene base level fall [Belmont, 2011]. The floodplains become progressively narrower with distance downstream through the knick zone. Confined flows with a relatively steep gradient are less inclined to deposit sediment, so decadal scale net sediment storage is minimal. One important implication of the steep knick zone in the lower reaches of the network is that sediment delivery ratios increase with downstream distance, contrary to many systems where sediment delivery ratios have been demonstrated, or assumed, to decrease downstream [NRCS, 1983].

Ravines play a complicated role in sediment storage and release. In general, ravines are net degradational, as discussed above. However, landslides and woody debris jams can cause backwater conditions in the otherwise steep channels. As a result, a significant amount of sediment can be temporarily stored in fill terraces, similar to the alluvial storage behind small dams discussed in the UPRW above. Sediment stored in a fill terrace can be excavated over a relatively short period of time when the physical barrier causing the backwater conditions is breached. Fill terraces of various sizes have been observed in ravines throughout the Le Sueur watershed. Because of the morphology of the ravines and poor filtering of dense ravine-bottom vegetation in the bare-earth lidar DEM, fill terraces can often be identified from the lidar DEM, but the volume of sediment trapped in fill terraces cannot readily be measured other than in the field.

\subsection{Assembling the Pieces}

Sediment budgets have been established for the Le Sueur watershed using HSPF [Tetra Tech, Inc., 2008], WEPP [Maalim, 2009], and SWAT [Folle, 2010]. Calibration and validation of these models have produced contrasting results [Wilcock, 2009]. The primary data used to calibrate the models is total suspended sediment (TSS) loading measured from a gauge network in the watershed. Although the network is relatively extensive with a gauge above and below the knick zone in each of the three primary subwatersheds and a long-running gauge at the watershed mouth, a fundamental problem arises in that the available sediment measurements used for load computation do not distinguish between different sources. Table 2 shows sediment loads measured at gauging stations throughout the watershed, both above and below the knickpoint.

Loads measured at the upper gauges in each watershed are primarily derived from uplands and stream banks, but the proportion of sediment derived from each source cannot be determined and might be expected to differ in dry versus wet years. Sediment yield increases dramatically between the upper and lower gauges on each tributary. This corresponds

Table 2. Sediment Loads for All Years of Record for Each Gauge in the Le Sueur Watershed

\begin{tabular}{|c|c|c|c|c|c|c|c|c|c|c|}
\hline \multirow[b]{2}{*}{ Basin } & \multirow[b]{2}{*}{ Contributing Drainage Area $\left(\mathrm{km}^{2}\right)$} & \multicolumn{9}{|c|}{ TSS Load $\left(\mathrm{Mg} \mathrm{yr}^{-1}\right)$} \\
\hline & & 2001 & 2002 & 2003 & 2004 & 2005 & 2006 & 2007 & 2008 & 2009 \\
\hline Upper Maple & 800 & - & - & - & - & - & 7,900 & 13,300 & 6,100 & 3,500 \\
\hline Lower Maple & 880 & - & - & 18,600 & 101,200 & 85,100 & 22,300 & 37,900 & 22,300 & 4,900 \\
\hline Upper Cobb & 335 & - & - & - & 7,500 & 8,200 & 4,000 & 4,400 & 3,100 & 1,600 \\
\hline Lower Cobb & 735 & - & - & - & - & - & 33,400 & 21,800 & 14,600 & 6,300 \\
\hline Upper Le Sueur & 870 & - & - & - & - & - & - & 42,200 & 22,400 & 4,300 \\
\hline Mid Le Sueur & 1210 & - & - & - & - & - & 86,600 & 74,600 & 42,800 & 13,400 \\
\hline Mouth Le Sueur & 2880 & 346,500 & 90,200 & 71,100 & 338,000 & 219,300 & 135,400 & 136,400 & 86,300 & 29,100 \\
\hline
\end{tabular}


to increasing prevalence of nonupland sediment sources such as bluffs and ravines but may also be due to increased connectivity of uplands to the channel and therefore higher sediment delivery ratios. Although the gauge data provide a good indication of the magnitude of sediment flux, it cannot inform about the location and mechanism of sediment supply.

Geochemical fingerprinting provides an alternative approach to constraining upland sediment yields. In the Le Sueur, meteoric lead-210 $\left({ }^{210} \mathrm{~Pb}\right)$ and beryllium-10 $\left({ }^{10} \mathrm{Be}\right)$ have been used in combination to quantify the proportion of sediment derived from uplands. Both tracers exhibit high concentrations in upland soils and low concentrations in bluffs and ravines. However, sediment temporarily stored in floodplains is diminished in ${ }^{210} \mathrm{~Pb}$ and enriched in ${ }^{10} \mathrm{Be}$ concentration. Therefore, if used independently, either of the tracers would be systematically biased depending on the amount of channel-floodplain sediment exchange. When the two tracers are used in combination, this bias can be corrected. Understanding the geochemical systematics of the tracers as well as mix of geomorphic processes conveying the sediment are both essential in implementing an effective fingerprinting study.

When used together, sediment gauging and sediment fingerprinting can be used to constrain both the proportion and rate of sediment supply from different landform units. By using multiple lines of evidence, one can begin to address the problem of equifinality inherent in watershed modeling in which multiple parameter combinations can be tuned to get the "right" upland erosion rates. Without such information, a watershed erosion modeler often has little more than intuition on which to base decisions about parameter tuning. By further incorporating upscaled sediment yield estimates for different landform units, as discussed above, a reliable estimate of sediment sources and sinks can be developed.

\section{DISCUSSION}

Stream restoration, rehabilitation, and stabilization are increasingly proposed as an approach to resolve watershed sediment problems. To date, many projects have been opportunistic, based on the availability of land, space on a development site, or local stakeholder interest. This approach is not likely to efficiently achieve desirable water quality changes. Instead, a broader strategy is needed that can target the best opportunities for sediment load reduction. The need to place best management practices in locations promising the greatest efficiency requires a thorough understanding of the geomorphic processes associated with mechanical erosion and landform adjustment in the contemporary landscape. Careful identification and sampling of upland and lowland landforms can guide the stream management approach proposed to address water quality problems, particularly if mechanisms of sediment supply can be identified. Approaches used to reduce sediment supply from uplands include runoff control, channel stabilization to reduce tributary incision, and the use of vegetation and buffers to trap surface erosion before it is delivered to the channel network. In contrast, practices proposed to achieve sediment reductions in alluvial valleys attempt to reduce the evacuation of stored sediment and enhance the trapping of newly delivered sediment.

Although the effort involved in developing a reliable watershed sediment model can seem large, the costs will generally be small compared to those involved in implementing restoration and other actions to address watershed sediment issues. The potential savings and benefits of implementing an effective program can be substantial. The requirements for an accurate watershed sediment model are similar to those needed for informed targeting of sediment source reductions. Both require specificity regarding location, mechanisms, and rates of erosion and sediment deposition. Planning and design require development of an understanding of landscape organization, documentation of the effects of management practices on sediment production, and tracking of the locations of practice implementation and effectiveness thereof. Implementation without these tasks will make it difficult to satisfy watershed sediment yield objectives over the long term.

In the UPRW, delineation of upland and lowland landscape units, channel head locations, and the transition from erosional to depositional valley bottoms was based on analyses of air photos, elevation data, and other catalogued spatial information. Rates of erosion and storage in upland units were characterized using field observations and eventbased sampling. Integrative records used to constrain uncertain upland erosion and deposition estimates were based on sediment accumulation in ponds. Land cover data were necessary for upscaling local erosion rates to the watershed scale. Comparison of sediment yield values indicated that sediment yield increased from the edge of field to the outlet of first-order watersheds and that net storage occurred within the higher-order watersheds. This pattern cannot be captured in a simple delivery factor intended to link edge-of-field soil erosion rates to sediment supply to higher-order rivers.

Delineation of landscape elements in the Le Sueur watershed, including agricultural fields, bluffs, ravines, and the channel-floodplain system, used a combination of analyses exploiting high-resolution topography and air photos as well as field surveys and mapping. Adequately constraining rates of sediment inputs from each source required an understanding of erosion mechanisms. Upscaling estimates of erosion from a few features where detailed measurements can be 
made (e.g., a dozen bluffs) to similar features throughout the watershed required constraints on spatial variability and delineation of essential geomorphic features, such as distinguishing the proportion of bluffs that are actively undercut. Design of sampling and monitoring programs require critical evaluation of these factors as well as lithology, relief, landform subunit, and land use. Future work needs to focus on automating the processes by which landscape elements can be identified, enhancing techniques for geomorphic change detection on spatially extensive landforms, and accounting for uncertainty in identification, change detection, and upscaling.

Sediment production, transport, and storage for individual landscape units must be upscaled in a geomorphically informed fashion. The advent of widespread coverage of highresolution elevation data, the availability of long-term air photo records, and the power of spatial data software offer excellent resources for upscaling in a superior, topographically sensitive fashion. Landform-specific sediment flux observations provide a basis for transferring data to appropriate locations within a catchment and linking the components together in a defensible manner.

Accurate treatment of sediment storage remains a difficult problem that can be addressed by constraining a sediment budget using sedimentation records of a decadal time scale or longer in order to integrate over a range of runoff and climatic conditions. Such observations of channel enlargement and sediment yield in first-order Mid-Atlantic Piedmont watersheds indicate that sediment storage is currently minimal, and sediment production is substantial in contemporary upland valleys. This contrasts with the conclusion of Costa [1975] that over half the sediment eroded during peak nineteenth century Piedmont agriculture remains stored in colluvial sheet wash deposits.

Variability in higher-order tributaries set within alluvial valleys requires consideration of base level controls and the role of large storms in setting annual to decadal sediment delivery patterns. Recent measurements indicate that contemporary floodplains in the Mid-Atlantic region are actively storing sediment, but the temporal and spatial limits to storage are not well documented [Schenk and Hupp, 2009; Noe and Hupp, 2009]. Comparison of third- and fifth-order alluvial valleys in the UPRW indicated that storage opportunities increase with drainage area. Local geologic conditions that govern valley geometry can strongly influence the availability of storage opportunities. The narrow gorges in the Piedmont fall zone are an example of a geologic feature that limits the capacity for floodplain development. However, the constriction also provides a hydraulic control that can affect sediment accumulation trends upstream.

Similarly, the Le Sueur channel-floodplain network exhibits distinct zones (agricultural ditches, ravines, low-gradient natural channels, and high-gradient natural channels) that must be delineated and treated separately for the purpose of estimating watershed sediment patterns. As discussed above, the sediment transport and storage dynamics differ significantly in each of these zones, so identifying if or where a problem exists and considering various stream restoration solutions to the problem must be done in a context-sensitive manner.

Given the large inherent uncertainty in any estimate of sediment erosion, transport, and storage, a credible watershed sediment model requires the use of multiple lines of evidence to constrain the estimated values. Regardless of the methods used, a sediment supply prediction that relies on a single estimate, or calculates budget terms as a residual, cannot produce reliable results. Approaches that rely on sediment concentration measurements and sediment rating curves are not only subject to considerable error, but do not provide a basis for prediction under altered conditions, do not identify actionable sources for locations between gauges, and can involve considerable, often prohibitive logistics and expense in order to build a data set across multiple spatial scales. Approaches based on local erosion measurements provide the observations and interpretation needed to specify the mechanism and location relevant for restoration efforts, but face considerable uncertainty in upscaling episodic and nonlinear rates. Sediment fingerprinting offers important advantages for source identification, but generally provides only percentages from different sources. An effective fingerprinting campaign can be defined using a combination of deposited sediment and sediment in transport, although this raises logistical issues similar to direct load measurements [Rowan et al., 2000]. All of these methods can be used in combination to improve the accuracy of sediment supply and yield estimates, although the strongest constraint, and therefore the most useful for developing a credible sediment budget, is a record of erosion or sedimentation that spans both spatial and temporal scales. It is very difficult to develop a credible sediment budget without some estimate of integrated erosion or deposition for the entire watershed over decadal or longer periods.

Observations of sediment accumulation in impoundments can be used to constrain the sediment yield estimate and related error. Impoundment measurements can be obtained through direct measurement of smaller structures and via the monitoring and maintenance that government agencies pursue for safety, water supply, and storm water quantity management purposes. The record of reservoir sedimentation is growing, and a concerted effort is underway to organize and distribute this information (http://ida.water.usgs.gov/ressed/), which can provide an invaluable constraint on future sediment yield estimates. An important opportunity can be realized 


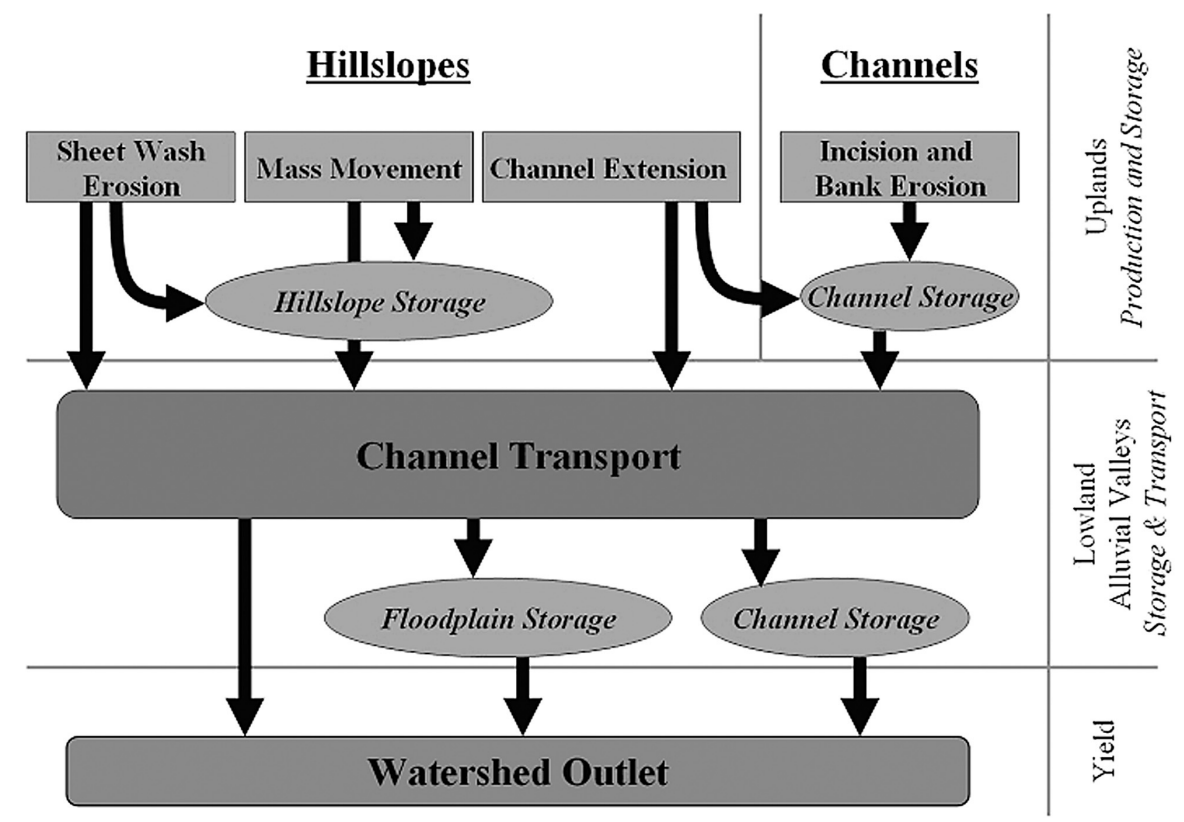

Figure 9. Watershed sediment budgeting framework

from better coordination with watershed maintenance efforts. For example, monitoring of sediment accumulation in reservoirs, ponds, and storm water facilities may be achieved as part of water quality and storage maintenance purposes.

Sediment accumulation in UPRW was determined for watersheds from first- to fifth-order and for time periods of one to many decades. In the case of the Le Sueur River, we took advantage of a well-defined incision history where the initial surface elevation and the timing of base level drop are

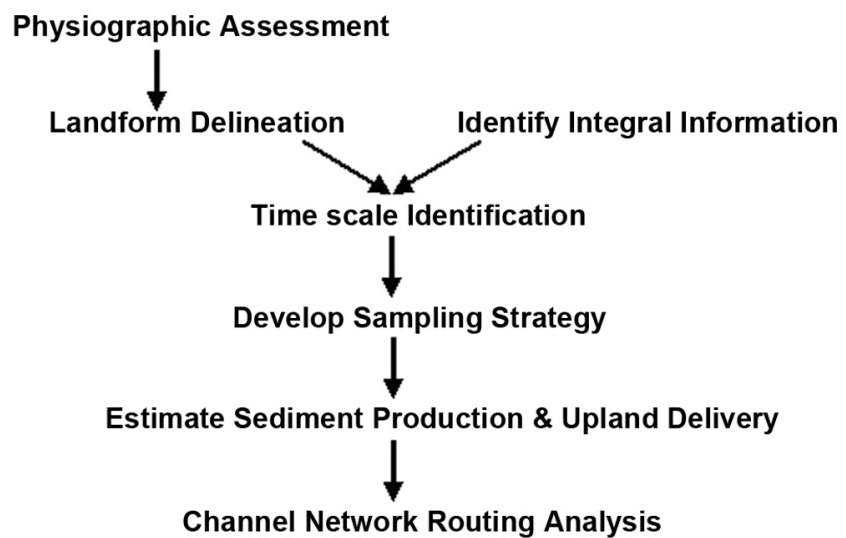

Figure 10. Watershed sediment process and yield analysis framework. precisely known to compute long-term sediment evacuation rates. Ongoing work will constrain the unsteady rates of knick migration and valley excavation over time throughout the Holocene. These data and hydrologic reconstructions combine to constrain natural background turbidity levels.

A broad conceptual framework can be proposed to aid in organization of a watershed sediment model. Landscape delineation, estimates of sediment yield in individual landscape units, and an approach for upscaling, coupling, and routing local sediment yield are the starting elements of any approach. Figure 9 provides a simple schematic of common elements of a watershed sediment model. Reid and Dunne [1996] provide an excellent handbook for evaluating the different parts of the budget. The role of zero- and first-order valleys, upland channels in Figure 9, in producing and storing sediment is poorly represented in any modeling approach, and improvements in that regard are a priority.

Figure 10 outlines a conceptual sequence of activities that can be used to organize efforts to develop an estimate of sediment supply or yield and address the scaling challenges of matching watershed models to sediment budgets. Before identifying modeling time scales, it is necessary to delineate the potential dominant sources of sediment and identify the types of integral data (reservoirs, long-running gauges, sediment fingerprinting, historical channel analysis) that might be available and reliable. Once the units and time scale are identified, an appropriate sampling strategy 
can be developed. This may combine field observations of erosion and deposition, historic analysis of slope and channel shift, and supporting information regarding land use and hydrologic alteration. By combining this information, it should be possible to compare upland sediment production to integral measures of sediment yield in a way that identifies the location and rates of sediment erosion and storage. When scaling up to larger watersheds, an approach for routing sediment along channels, including an estimate of net storage, is needed.

\section{SUMMARY}

A variety of factors, relief, landscape history, climate, and land use history cause the locations, mechanisms, and rates of sediment production and storage to vary in space and time. Recent advances in monitoring technology, geochemical techniques, high-resolution topography data acquisition and analysis, geographic information system software, and numerical modeling approaches provide new opportunities to constrain geomorphic rates, upscale them in a geomorphically relevant fashion, and synthesize sediment dynamics at the watershed scale. In the two examples examined here, the upper Patuxent River in Maryland and the Le Sueur River in Minnesota, the mechanisms and many of the sediment budget components are substantially different. Remarkably, the upstream-to-downstream position of dominantly erosional and depositional landscapes is different between the two watersheds. The UPRW has a more typical erosional-todepositional sequence, whereas because of low gradient and the Holocene base level drop, erosional reaches in the Le Sueur occur down valley of low-gradient reaches with substantial storage. Nonetheless, there are common challenges and themes in defining an effective watershed sediment model. In both cases, reliable estimates of sediment yield depend essentially on the accurate identification of sediment sources and sinks and, hence, require careful delineation of landscape units. Upscaling local contributions to watershed sediment yield requires reliable estimates of sediment transport across multiple time scales and the use of multiple lines of evidence to constrain uncertain estimates.

\section{REFERENCES}

Allmendinger, N. E., J. E. Pizzuto, G. E. Moglen, and M. Lewicki (2007), A sediment budget for an urbanizing watershed, 19511996, Montgomery County, Maryland, USA, J. Am. Water Resour. Assoc., 43(6), 1-16, doi:10.1111/j.1752-1688.2007.00122.x.

Arnold, J. G., R. Srinivasan, R. S. Muttiah, and J. R. Williams (1998), Large-scale hydrologic modeling and assessment. I: Model development, J. Am. Water. Resour. Assoc., 34(1), 73-89.
Bankhead, N. L., and A. Simon (2010), Hydrologic and hydraulic effects of riparian root networks on stream bank stability: Is mechanical root-reinforcement the whole story?, Geomorphology, 116, 353-362.

Belmont, P. (2011), Floodplain width adjustments in response to rapid base level fall and knickpoint migration, Geomorphology, 128(1-2), 92-102.

Bicknell, B. R., J. C. Imhoff, J. L. Kittle Jr., T. H. Jobes, and A. S. Donigian Jr. (2001), Hydrologic Simulation Program - Fortran. HSPF version 12 users manual. report, U.S. Hydrol. Anal. Software Support Program, U.S. Geol. Surv., Reston, Va.

Bierman, P. R., J. M. Reuter, M. Pavich, A. C. Gellis, M. W. Caffee, and J. Larsen (2005), Using cosmogenic nuclides to contrast rates of erosion and sediment yield in a semi-arid, arroyo-dominated landscape, Rio Puerco Basin, New Mexico, Earth Surf. Processes Landforms, 30, 935-953.

Blann, K. L., J. L. Anderson, G. R. Sands, and B. Vondracek (2009), Effects of agricultural drainage on aquatic ecosystems: A review, Crit. Rev. Environ. Sci. Technol., 39(11), 909-1001.

Bloom, A. L. (1998), Geomorphology - A Systematic Analysis of Late Cenozoic Landforms, 3rd ed., Prentice Hall, Upper Saddle River, N. J.

Boomer, K. B., D. E. Weller, and T. E. Jordan (2008), Empirical models based on the universal soil loss equation fail to predict sediment discharges from Chesapeake Bay catchments, J. Environ. Qual., 37, 79-89, doi:10.2134/jeq2007.0094.

Brush, G. S. (2008), Historical land use, nitrogen, and coastal eutrophication: A paleoecological perspective, Estuaries Coasts, 32, 18-28, doi:10.1007/s12237-008-9106-z.

Clayton, L., and S. R. Moran (1982), Chronology of late-Wisconsinan glaciations in middle North America, Quat. Sci. Rev., 1, 5582, doi:10.1016/0277-3791(82)90019-1.

Cleaves, E. T. (1974), The Towson quadrangle, geologic map, Md. Geol. Surv., Baltimore.

Cleaves, E. T., A. E. Godfrey, and O. P. Bricker (1970), Geochemical balance of a small watershed and its geomorphic implications, Geol. Soc. Am. Bull., 81, 3015-3032.

Cleaves, E. T., D. W. Fisher, and O. P. Bricker (1974), Chemical weathering of serpentinite in the Eastern Piedmont of Maryland, Geol. Soc. Am. Bull., 85, 437-444.

Cohn, T. A., L. L. Delong, E. J. Gilroy, R. M. Hirsch, and D. K. Wells (1989), Estimating constituent loads, Water Resour. Res., 28, 937-942.

Corenblit, D., J. Steiger, A. M. Gurnell, E. Tabacchi, and L. Roques (2009), Control of sediment dynamics by vegetation as a key function driving biogeomorphic succession within fluvial corridors, Earth Surf. Processes Landforms, 34, 1790-1810.

Costa, J. E. (1975), Effects of agriculture on erosion and sedimentation in the Piedmont province, Maryland, Geol. Soc. Am. Bull., $86,1281-1286$.

Costa, J. E., and E. T. Cleaves (1984), The Piedmont landscape of Maryland: A new look at an old problem, Earth Surf. Processes Landforms, 9, 59-74, doi:10.1002/esp.320090107. 
De Alba, S. (2001), Modeling the effects of complex topography and patterns of tillage on soil translocation by tillage with mouldboard plough, J. Soil Water Conserv., 56(4), 335-345.

Dean, D. J., and J. C. Schmidt (2011), The role of feedback mechanisms in historic channel changes of the lower Rio Grande in the Big Bend region, Geomorphology, 126(3-4), 333-349.

De Vente, J., J. Poesen, M. Arabkhedri, and G. Verstraeten (2007), The sediment delivery problem revisited, Prog. Phys. Geogr., $31(2), 155-178$.

Donigian, A. S., Jr., and W. C. Huber (1991), Modeling of nonpoint source water quality in urban and non-urban areas, Rep. EPA/600/ 3-91/039, Environ. Res. Lab., U.S. Environ. Prot. Agency, Athens, Ga.

Dunne, T., and L. B. Leopold (1978), Water in Environmental Planning, W.H. Freeman, San Francisco, Calif.

Engstrom, D. R., J. E. Almendinger, and J. A. Wolin (2009), Historical changes in sediment and phosphorus loading to the upper Mississippi River: Mass-balance reconstructions from the sediments of Lake Pepin, J. Paleolimnol., 41, 563-588.

Flanagan, D. C., and M. A. Nearing (1995), USDA Water Erosion Prediction Project: Hillslope profile and watershed model documentation, NSERL Rep. 10, Natl. Soil Erosion Res. Lab., Agric. Res. Serv., U.S. Dep. of Agric., West Lafayette, Ind.

Folle, S. M. (2010), SWAT modeling of sediment, nutrients and pesticides in the Le-Sueur River watershed, south-central Minnesota, Ph.D. dissertation, Univ. of Minn., Minneapolis.

Foster, G. R., and L. J. Lane (1987), User requirements: USDA Water Erosion Prediction Project (WEPP), NSERL Rep. 1, Natl. Soil Erosion Res. Lab., Agric. Res. Serv., U.S. Dep. of Agric., West Lafayette, Ind.

Gottschalk, L. C. (1945), Effects of soil erosion on navigation in upper Chesapeake Bay, Geogr. Rev., 35, 219-238.

Gottschalk, L. C. (1948), Analysis and use of reservoir sedimentation data, in Proceedings of the 1st Federal Interagency Sedimentation Conference, May 6-8, 1947, Denver, Colorado, pp. $131-141$.

Gran, K. B., P. Belmont, S. S. Day, C. Jennings, A. Johnson, L. Perg, and P. R. Wilcock (2009), Geomorphic evolution of the Le Sueur River, MN, USA, and implications for current sediment loading, in Management and Restoration of Fluvial Systems with Broad Historical Changes and Human Impacts, edited by L. A. James, S. L. Rathburn, and G. R. Whittecar, Spec. Pap. Geol. Soc. Am., 451, 119-130.

Grumet, R. S. (2000), Bay, plain, and piedmont: A landscape history of the Chesapeake heartland from 1.3 billion years ago to 2000. The Chesapeake Bay Heritage Context Project, report, 183 pp., Natl. Park Serv., U.S. Dep. of the Inter., Annapolis, Md.

Hack, J. T. (1957), Studies of longitudinal stream profiles in Virginia and Maryland, U.S. Geol. Surv. Prof. Pap., 294-B, $97 \mathrm{pp}$.

Hack, J. T. (1960), Interpretation of erosional topography in humid temperate regions, Am. J. Sci., 258A, 80-97.

Happ, S. C. (1945), Sedimentation in South Carolina Piedmont valleys, Am. J. Sci., 243, 113-126.
Hassett, B., M. Palmer, E. Bernhardt, S. Smith, J. Carr, and D. Hart (2005), Restoring watersheds project by project: Trends in Chesapeake Bay tributary restoration, Front. Ecol. Environ., 3(5), 259-267.

Hooke, R. L. B. (2000), On the history of humans as geomorphic agents, Geology, 28, 843-846.

Howard, A. D. (1999), Simulation of gully erosion and bi-stable landforms, in Incised River Channels, edited by S. E. Darby and A. Simon, John Wiley, New York.

Interstate Commission on the Potomac River Basin (ICPRB) (2006), Modeling framework for simulating hydrodynamics and water quality in the Prettyboy and Loch Raven Reservoirs, report, Rockville, Md.

Jacobsen, R. B., and D. J. Coleman (1986), Stratigraphy and recent evolution of Maryland Piedmont flood plains, Am. J. Sci., 286, 617-637.

Jain, V., K. Fryirs, and G. Brierley (2008), Where do floodplains begin? The role of total stream power and longitudinal profile form on floodplain initiation processes, Geol. Soc. Am. Bull., 120, 127-141, doi:10.1130/B26092.1.

Jennings, C. E. (2010), Draft digital reconnaissance surficial geology and geomorphology of the LeSueur River watershed (Blue Earth, Waseca, Faribault and Freeborn counties in south-central MN), report, Open File Rep. 10-03, Minn. Geol. Surv., St. Paul. (Available at http://purl.umn.edu/98055)

Kelley, D. W., and E. A. Nater (2000), Historical sediment flux from three watersheds into Lake Pepin, Minnesota, USA, J. Environ. Qual., 29, 561-568.

Langendoen, E. J. (2000), CONCEPTS - CONservational Channel Evolution and Pollutant Transport System, Res. Rep. 16, Natl. Sediment. Lab., Agric. Res. Serv., U.S. Dep. of Agric., Oxford, Miss.

Langendoen, E. J. (2002), CONCEPTS: A process-based computer model of instream hydraulic and geomorphic processes hydrologic modeling for the 21st century, paper presented at Second Federal Interagency Hydrologic Modeling Conference, Subcomm. on Hydrol and Sediment., Advis. Comm. on Water Inf., Las Vegas, Nev., 28 July to 1 Aug.

Langland, M. J., and T. M. Cronin (Eds.) (2003), A summary report of sediment processes in Chesapeake Bay and watershed, U.S. Geol. Surv. Water Resour. Invest. Rep., 03-4123, 109 pp.

Langland, M. J., P. L. Lietman, and S. Hoffman (1995), Synthesis of nutrient and sediment data for watersheds within the Chesapeake Bay drainage basin, U.S. Geol. Surv. Water Resour. Invest. Rep., 95-4233.

Lauer, J. W., and G. Parker (2008a), Net local removal of floodplain sediment by river meander migration, Geomorphology, 96, $123-149$.

Lauer, J. W., and G. Parker (2008b), Modeling framework for sediment deposition, storage, and evacuation in the floodplain of a meandering river: Application to the Clark Fork River, Montana, Water Resour. Res., 44, W08404, doi:10.1029/2006WR005529.

Lizarraga, J. S. (1999), Nutrient and sediment concentrations, trends, and loads from five subwatersheds in the Patuxent River 
Basin, Maryland, 1986-96, U.S. Geol. Surv. Water Resour. Invest. Rep., 98-4221.

Maalim, F. K. (2009), Modeling potential erosion and sediment contribution from upland agricultural areas: A case study of Le Sueur River Watershed, Minnesota, M.S. thesis, Fla. Int. Univ., Miami.

Matsch, C. L. (1983), River Warren, the southern outlet of Lake Agassiz, in Glacial Lake Agassiz, edited by J. T. Teller and L. Clayton, Geol. Assoc. Can. Spec. Pap., 26, 232-244.

Meade, R. H. (1982), Sources, sinks, and storage of river sediment in the Atlantic drainage of the United States, J. Geol., 90, 235-252.

Minnesota Pollution Control Agency (2008), State of the Minnesota River, report, Minn. River Basin Data Cent., Minn. State Univ., Mankato. (Available at http://mrbdc.wrc.mnsu.edu/reports/ report.html)

Montgomery, D. (2007), Dirt: The Erosion of Civilizations, 295 pp., Univ. Calif. Press, Berkeley.

Natural Resources Conservation Service (NRCS) (1983), Sediment sources, yields, and delivery ratios, in National Engineering Handbook, Part 632, Sedimentation Geology, chap. 6, p. 11, U.S. Dep. of Agric., Washington, D. C.

Neitsch, S. L., J. G. Arnold, J. R. Kiniry, and J. R. Williams (2005), Soil and water assessment tool, theoretical documentation, version 2005, report, Grassland, Soil and Water Res. Lab., Agric. Res. Serv. and Blackland Res. Cent., Texas Exp. Stn., Temple, Tex.

Noe, G. B., and C. R. Hupp (2009), Retention of riverine sediment and nutrient loads by Coastal Plain floodplains, Ecosystems, 12, 728-746, doi:10.1007/s10021-009-9253-5.

Novotny, E. V., and H. G. Stefan (2007), Stream flow in Minnesota: Indicator of climate change, J. Hydrol., 334, 319-333.

Patric, J. H., J. O. Evans, and J. D. Helvey (1984), Summary of sediment yield data from forested land in the United States, $J$. For, 82(2), 101-104.

Pavich, M. J. (1989), Regolith residence time and the concept of surface age of the Piedmont "peneplain", Geomorphology, 2, $181-196$.

Perona, P., P. Molnar, M. Savina, and P. Burlando (2009), An observation-based stochastic model for sediment and vegetation dynamics in the floodplain of an Alpine braided river, Water Resour. Res., 45, W09418, doi:10.1029/2008WR007550.

Phillips, J. D. (1991), Fluvial sediment budgets in North Carolina Piedmont, Geomorphology, 4, 231-241.

Reger, J. P., and E. T. Cleaves (2003), Physiographic map of Maryland, map, Md. Geol. Surv., Baltimore.

Reid, L. M., and T. Dunne (1996), Rapid Evaluation of Sediment Budgets, Catena, Reiskirchen, Germany.

Reid, L. M., and T. Dunne (2003), Sediment budgets as an organizing framework in fluvial geomorphology, in Tools in Fluvial Geomorphology, edited by G. M. Kondolf and H. Piegay, pp. 463-500, John Wiley, Chichester, U. K.

Renard, K. G., G. R. Foser, G. A. Weesles, D. K. McCool, and D. C. Yoder (1997), Predicting Soil Erosion by Water: A Guide to Conservation Planning with the Revised Universal Soil Loss
Equation (RUSLE), Agric. Handb., vol. 703, Agric. Res. Serv., U.S. Dep. of Agric., Washington, D. C.

Roehl, J. (1962), Sediment source areas, delivery rates and influencing morphological factors, Int. Assoc. Sci. Hydrol. Publ., 59, 202-213.

Rowan, J. S., P. Goodwill, and S. W. Franks (2000), Uncertainty estimation in fingerprinting suspended sediment sources, in Tracers in Geomorphology, edited by I. D. L. Foster, pp. 279-290, John Wiley, Chichester, U. K.

Scatena, F. N. (1987), Sediment budgets and delivery in a suburban watershed, Ph.D. dissertation, Johns Hopkins Univ., Baltimore, Md.

Schenk, E. R., and C. R. Hupp (2009), Legacy effects of colonial millponds on floodplain sedimentation, bank erosion, and channel morphology, mid-Atlantic, USA, J. Am. Water Resour. Assoc., 45(3), 597-606, doi:10.1111/j.1752-1688. 2009.00308.x.

Schueler, T. R., and J. Lugbill (1990), Performance of current sediment control measures at Maryland construction sites, report, Md. Dep. of the Environ., Baltimore.

Simon, A., and A. J. C. Collison (2002), Quantifying the mechanical and hydrologic effects of riparian vegetation on stream bank stability, Earth Surf. Processes Landforms, 27, 527-546.

Simon, A., A. Curini, S. E. Darby, and E. J. Langendoen (2000), Bank and near-bank processes in an incised channel, Geomorphology, 35, 193-217.

Smith, S. M. C., L. Linker, and J. P. Halka (2008), Stream information exchange-Fine sediment and the Chesapeake Bay, Workshop Proceedings, report, Md. Dep. of Nat. Resour., Annapolis. (Available at http://archive.chesapeakebay.net/pubs/subcommittee/ nsc/sedwg/Fine_Sediment_Synthesis_FINAL.pdf)

Smith, S. M. C., L. Gutierrez, and A. Gagnon (2009), Maryland streams, take a closer look, report, Watershed Serv., Md. Dep. of Nat. Resour., Annapolis.

Soil and Water Conservation Society (2003), Conservation implications of climate change: Soil erosion and runoff from cropland, report, Ankeny, Iowa. (Available at http://www.swcs.org/ documents/filelibrary/advocacy_publications_before_2005/ Climate_changefinal_112904154622.pdf)

Strahler, A. N. (1957), Quantitative analysis of watershed geomorphology, Eos Trans. AGU, 8(6), 913-920.

Tetra Tech Inc. (2008), Minnesota River Basin turbidity TMDL and Lake Pepin excessive nutrient TMDL: Model calibration and validation report, report, 240 pp., Minn. Pollut. Control Agency, St. Paul.

Thorleifson, L. H. (1996), Review of Lake Agassiz history, in Sedimentology, Geomorphology and History of the Central Lake Agassiz Basin, Field Trip Guideb., vol. B2, edited by J. T. Teller et al., pp. 55-84, Geol. Assoc. of Can., Winnipeg, Manit.

Trimble, S. W. (1977), The fallacy of stream equilibrium in contemporary denundation studies, Am. J. Sci., 277, 876-887.

Trimble, S. W. (1999), Decreased rates of alluvial sediment storage in the Coon Creek basin, Wisconsin, 1975-93, Science, 285, 1244-1246, doi:10.1126/science.285.5431.1244. 
Trimble, S. W., and P. Crosson (2004), U.S. soil erosion ratesMyth and reality, Science, 289, 248-250.

U. S. Environmental Protection Agency (U.S. EPA) (2008), A report to the citizens of the bay region, Chesapeake Bay: Health and Restoration Assessment, Rep. EPA-903-R-08-002 (CBP/ TRS-291-08), Chesapeake Bay Program, Annapolis, Md.

U. S. Environmental Protection Agency (U.S. EPA) (2010), Chesapeake Bay total maximum daily load for nitrogen, phosphorus and sediment, report, Annapolis, Md. (Available at http:// www.epa.gov/reg3wapd/pdf/pdf_chesbay/FinalBayTMDL/ CBayFinalTMDLExecSumSection1through3_final.pdf)

Verstraeten, G., and J. Poesen (2001), Modeling the long-term sediment trap efficiency of small ponds, Hydrol. Processes, 15(14), 2797-2819, doi:10.1002/hyp.269.

Walling, D. E. (1983), The sediment delivery problem, J. Hydrol., 65, 209-237.

Walling, D. E. (1999), Using fallout radionuclides in investigations of contemporary overbank sedimentation on the floodplains of British rivers, in Floodplains: Interdisciplinary Approaches, edited by S. B. Marriott and J. Alexander, Geol. Soc. Spec. Publ., 163, 41-59.

Walter, R. C., and D. J. Merritts (2008), Natural streams and the legacy of water powered mills, Science, 319, 299-304, doi:10.1126/science.1151716.

Wilcock, P. (2009), Identifying sediment sources in the Minnesota River Basin, Minnesota River Sediment Colloquium, report, Minn. Pollut. Control Agency, St. Paul. (Available at http:// www.lakepepinlegacyalliance.org/SedSynth_FinalDraft-formatted. pdf)

Williams, J. R. (1975), Sediment-yield prediction with universal equation using runoff energy factor, in Present and Prospective
Technology for Predicting Sediment Yields and Sources, pp. 244- 252, Agric. Res. Serv., U.S. Dep. of Agric., Washington, D. C.

Wing, S. (2009), Classifications of ravine morphometrics in the Minnesota River Basin using GIS-based terrain analysis, M.S. thesis, Univ. of Minn., Minneapolis.

Wischmeier, W., and D. Smith (1978), Predicting Rainfall Erosion Losses: A Guide to Conservation Planning, Agric. Handb., vol. 537, Agric. Res. Serv., U.S. Dep. of Agric., Washington, D. C.

Wolman, M. G. (1967), A cycle of sedimentation and erosion in urban river channels, Geogr. Ann., 49(2-4), 385-395.

Wolman, M. G. (1977), Changing needs and opportunities in the sediment field, Water Resour. Res., 13, 50-54.

Wolman, M. G., and R. Gerson (1978), Relative scales of time and effectiveness of climate in watershed geomorphology, Earth Surf. Processes, 3, 189-208.

Wolman, M. G., and A. P. Schick (1967), Effects of construction on fluvial sediment, urban and suburban areas of Maryland, Water Resour. Res., 3, 451-464.

Yorke, T. H., and W. J. Herb (1978), Effects of urbanization on streamflow and sediment transport in the Rock Creek and Anacostia River basins, Montgomery County, Maryland, 1962-74, U.S. Geol. Surv. Prof. Pap., 1003, 71 pp.

P. Belmont, Department of Watershed Sciences, Utah State University, Logan, UT 84332, USA.

S. M. C. Smith and P. R. Wilock, Department of Geography and Environmental Engineering, Johns Hopkins University, Baltimore, MD 21218, USA. (ssmith7520@aol.com) 
